\title{
إنتاج تصميمات زخرفية للظواهر الطبيعية قائمة على تحليل النظم البنائية لنظرية المورفوجينيك.
}

\section{Producing decorative designs for natural phenomena based on the} structural systems analysis of morphogenesis theory.

أ.م.د// هند سعد محمد حسين عبيد

استاذ التصميم المساعد بقسم التصميم الزخرفية بكلية تربية فنية جامعة المنيا

\section{Assist. Prof. Dr. Hend Saad Mohammed Hussien Epaid}

Assistant Professor of Decorative Design.Faculty of art Education, Mina University.

Hend_epaid@mu.edu.eg

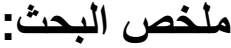

تكمن مشكلة البحث وتعد دراسة التصميم المورفوجينيك للمصمم إمكانية دراسة الجو هر الداخلي للظواهر الطبيعية العضوية مصدراً هاماً للرؤية التصميمية المعاصرة ومنطلقا جديداً لتدريس التصميمات الزخرفية التي تتشكل وفقا لخلاياها ومفر ادتها ، حيث يعطي الفرصة للمصمم الزخرفي الاستخدام التصميمات المسطحة والإيحاء بالتجسيم مما يوسع مدارك المصمم

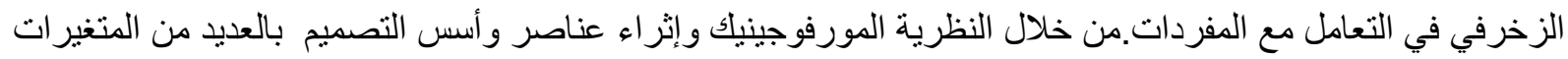
التشكيلية عبر نوظيفها بالكمبيونر جر افيك وذللك لتحديث الفكر الخاص بالتصميم الزخرفي في دراسة الظواهر الطبيعية في التصميم والتي أتاحت مجالات غير تقليدية في التصميم المعاصر . ويتحدد سؤال البحث في التساؤل التالي:- إلي أي مدي بستفبد المصمم الزخرفي من التصميم المورفوجينيك وما يستتبعة من نظم البنائية وما يتضمنه من الظو اهر الطبيعة يتشكل علي أساسه التصميم الزخرفي؟ أهداف البحث: يهدف البحث إلي التوظيف الجرافيكي للقيم الحركية للظواهر الطبيعة في فن المورفوجينيك خلال مجموعة من التصميمات الزخرفية. وطرح مداخل تجربيبة جديدة لبناء اللوحة الزخرفية في ضوء بنية النظام المورفوجينيك. و إنتاج مجموعة من التطبيقات العلمية مستفيدة من التوظيف الجرافيكي للكمبيوتر للمتغيرات الحركية ثنائية الإبعاد (الثعاب المرجانية وبلورات الثلج) من خلال فن المورفوجينيك. وتعد أهمية هذا البحث في التأكيد علي أهمية البناء التصميمي للشبكات التي تصاغ من خلالها الثعاب المرجانية وبلورات الثلج ، بما يضفي علية من إيحاء بالتجسيم , حيث يأخذ المصدم من الطبيعة مصادرة لصياغة وتتكيل مفرداتة وبنيته التصميمية باستخدام شبكة هندسية مسطحة وثابتة تنظم من خلالها مفردات عضوية مأخوذ من النظام الجيني لإعادة صياغة للاستفادة منه كمدخل جديد معاصر للظواهر الطبيعة في قسم التصميمات الزخرفية في كلية التربية الفنية. و اتبع البحث المنهج الوصفي التحليلي: القائم علي جمع المعلومات وتحليل النظم البنائية والحركة الفعلية القائمة علي نظرية المورفوجينيك وتحقيقها في نظم الثفرة الور اثية لاستخلاص المفردات و النظام البنائي والمجموعة اللونية وهذا فيما يتعلق بالإطار النظري للار اسة وتوظيفها بالتقنيات الحديثة في التصميمات الزخرفية باستخدام الكمبيوتر. والمنهج التجريبي: عمل تصميمات مبتكرة مرتبطة بالبناء التصميمي للحركة الفعلية للظو اهر الطبيعة (الثعاب المرجانية وبلور ات الثلج) القائمة علي نظرية المورفوجينيك ،حيث يحقق المصمم الزخرفي الاستخدام التصميمات المسطحة و الإيحاء

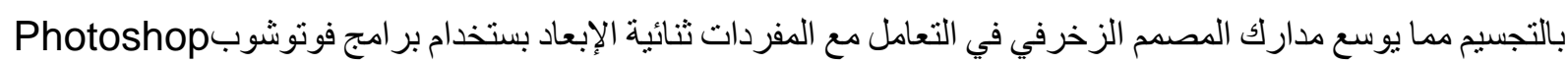
.Adobe illustrator ,

الكلمات المفتاحية: التصميم المورفوجينيك ـ التصميم المورفوجينيسيز - الظواهر الطبيعة ــ البنية ـ لفن الحيوي. 


\section{Abstract:}

The problem lies in the research and studying the morphogenic design of the designer is the possibility of studying the inner essence of organic natural phenomena, an important source for contemporary design vision and a new starting point for teaching decorative designs that are formed according to their cells and singularity, as it gives the decorative designer the opportunity to use flat designs and the suggestion of anthropomorphism, which broadens the perceptions of the decorative designer in dealing with vocabulary. Through morphogenic theory and enrichment of design elements and foundations with many plastic variables by employing them with computer graphics in order to update the thought of decorative design in the study of natural phenomena in design, which provided unconventional fields in contemporary design. The research question is determined in the following question: - To what extent does the decorative designer benefit from the morphogenic design and the consequent structural systems and the natural phenomena it contains, on the basis of which the decorative design is formed?

Research objectives: The research aims at the graphic employment of the kinetic values of the natural phenomena in the morphogenic art through a group of decorative designs. It proposes new experimental approaches for building the decorative painting in light of the morphogenic system structure. And the production of a set of scientific applications taking advantage of the computer graphic employment of two-dimensional kinematic variables (corals and ice crystals) through morphogenic art.

The importance of this research is to emphasize the importance of the design construction of networks through which coral reefs and snow crystals are formed, in a way that gives it the suggestion of anthropomorphism. The genetic system for reformulation to be used as a new contemporary introduction to natural phenomena in the Department of Decorative Designs in the Faculty of Art Education.

The research followed the analytical descriptive approach: based on collecting information and analyzing structural systems and actual movement based on the morphogenic theory and its investigation in the genetic code systems to extract the vocabulary, structural system and color group and this is related to the theoretical framework of the study and its use of modern techniques in decorative designs using the computer.

The experimental method: Creating innovative designs related to the design construction of the actual movement of natural phenomena (coral reefs and ice crystals) based on morphogenic theory, where the decorative designer achieves the use of flat designs and the suggestion of anthropomorphism, which broadens the perceptions of the decorative designer in dealing with the two-dimensional vocabulary using Photoshop and Adobe illustrator programs.

\section{Key words:}

morphogenic design - morphogenesis design - natural phenomena - structure - bio-art. 
ان يعبر المصدم عن روح العصر التي يسودها الفكر التجريبي و التقني التكنولوجي والقيم الحركية والإيقاع الحركي للمتغيرات ، وبفضل التطور ات العلمية خاصة بعد ظهور تكنولوجيا التقنيات الحديثة مثل بر امج الكمبيوتر و النقال واستخدام الليزر ، فقد استفاد منها المصمم وفتحت أمامه آفاق جديدة مكنته من الوصول إلي معالجات مبتكرة لموضو عات تشكيلية . تعد الطبيعة المصدر الرئيسي للمصمم ، حيث يتناول المصمم مفرداتة من الطبيعة من المظهر الخارجي لها ويعيد صياغتها

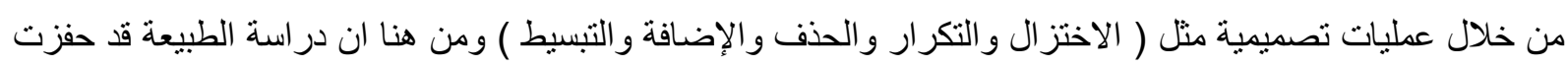
ظهور عدة تخصصات مثل الثكل الحيوي وعلم البيولوجيا الذي يتناول دراسة الخلية الني تتضمن النواة و البرونوبلازم و الجينات الور اثية ( الجينوم ) أو ما يطلق علية الدانا (DNA) ويتضح ذلك في شكل (1) يوضح حركته داخل الخلية وذلك من خلال مقطع في الخلية يبين موضع الجينوم كما في شكل (2) رسم تخطيطي للجينوم ( الثريط الور اثي ).

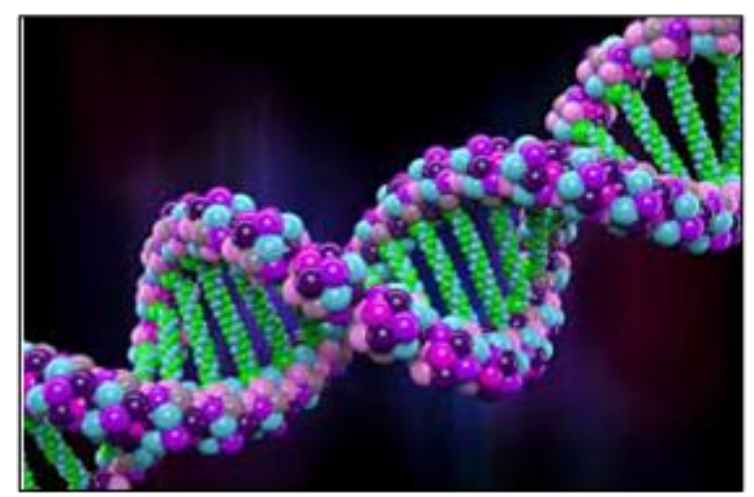

شكل (2) رسم تخطيطي للجينوم

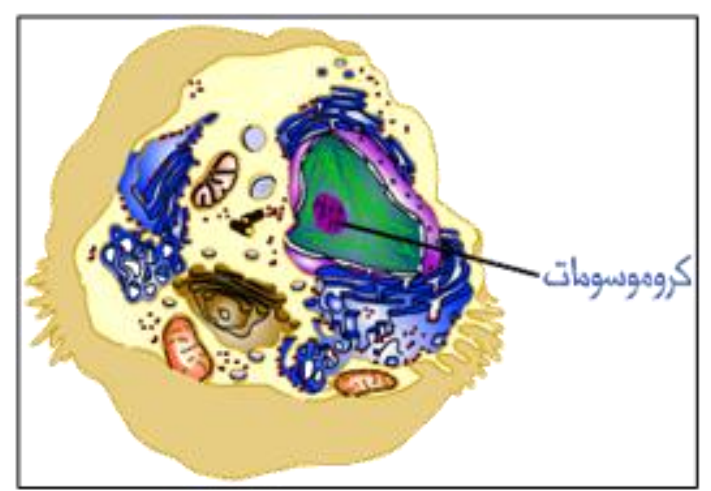

شكل (1) مقطع في الخُلبة لحضض النووي لثشفرة

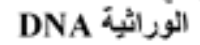

مما جعل إلي الإهتمام بدراسة التركيبة الوراثية للعناصر الطبيعة ، فهي مرتبطة بطبيعة التصميم ، وتعني بالفكر اولا

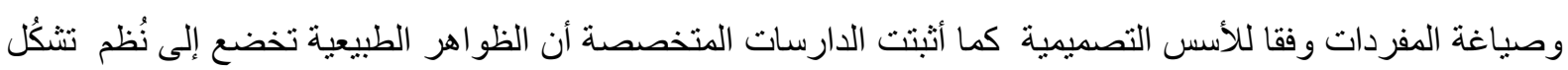
ناتجة عن" العلاقة بين المؤثرات الخارجية والدوافع الداخلية "التي تتحكم في شكل ونمط وتصنيف الظاهرة من حيث بنية الدلالات الثكلية أو ما يطلق عليها علميا المورفوجنتك Morphogenetic المنمنلة في النظام الخطي لشكل الظاهرة الخارجي أو ما تتركه من أثر ملحوظ خطى أو لونى أو حركي، فالكثف عن القو انين البنائية المستترة داخل عناصر الطبيعة

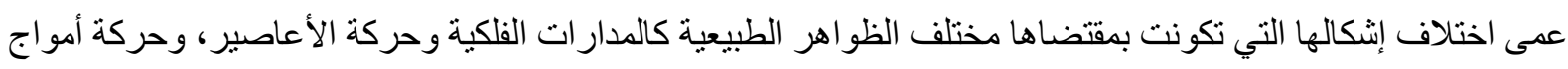

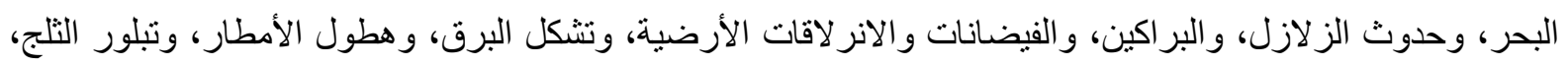

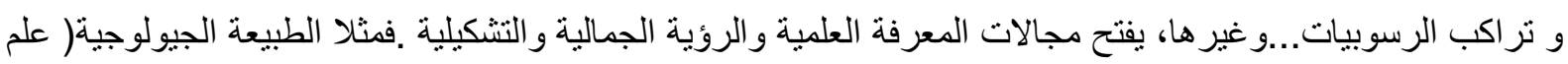

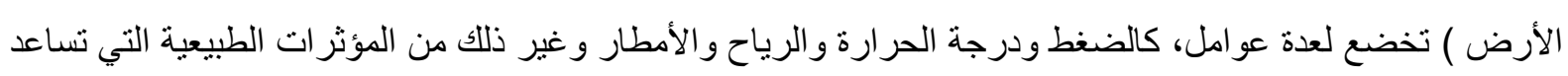
عمى تكوين الطبقات الرسوبية ومن خلال عامل الزمن ينم التفاعل الميكانيكي بين تلك الطبقات. و علم (المورفولوجيا) يعني بالدراسة التحليلية للأشكال من الطبيعة إلي التصميم حيث ينتبع الأسس العضوية للعمليات الناشئة عن نشاط كل كائن حي ، ويتناول مجال التصميم مصادر جوهرية في الطبيعة للإستفادة من جو هر تللك المكونات الطبيعة . و المظهر البنائي الجيني الداخلي و المظهر التركيبي الخارجي للعناصر الطبيعة وتتطلب مهار ات و علوم تقنية لانتقال الإشكال من الطبيعة إلي التصميم . مهين. 
ودر اسة التصميم المورفوجينيك ناتجة عن در اسة النظرية العضوية القائمة علي العمليات الحيوية التي تتشأ من نشاط أعضاء الكائن الحي كلها كنظام عضوي متكامل ، و هذه الدراسة نساعد المصمم الزخرفي علي نرتيب المفردات و العناصر و النظم البنائية لتقديم تصميم زخرفي معاصر . ماصن ويعطي مجال التصميم المورفوجينيك للمصدم الزخرفي إمكانية تتبع الهيئة الثكلية الخارجية ومظاهر ها المجسمة في الفراغ

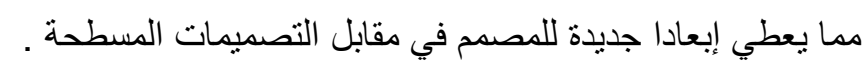
مجال التصميم المورفوجينيك احدث الدراسات التي تناولت مصادرها التصميم وقد سبقها عدة نظريات منها الهيولية و الفر اكتالات و التصميم الرقمي الذي يهتم بالإشكال الكسرية . وقد وضح توم ريتشي( Tom Ritchey, 2009 في در استه المقصود بالمورفولوجي بقوله :جاء مصطلح مورفولوجي Morphology

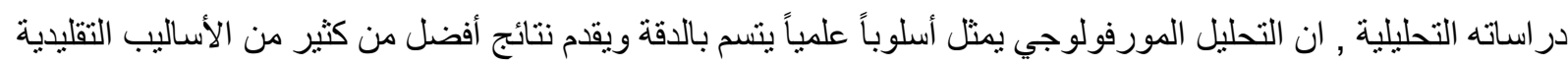
وهو يقوم علي تحليل الظو اهر أو القضية البحثية إلى مجموعة من الأفكار الفرعية إلى جزئية، ثم يعيد تركيب هذه الأفكار

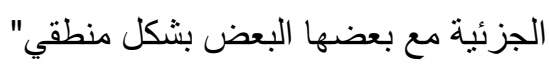
وقد وضع عالم الإحياء البريطاني ( روبرت شليدر الك) نظرية حول مجال تطور الثكل و التي عرفت جيدا من فبل الباحثين و النقاد في المجتمع العلمي و هذه النظرية قد أمدتنا بتفسير منطقي لنظرية (المورفوجينيك) من خلال النظرية وضع "شيلدر الك" رئر كيفية إثبات الإشكال الحية ليصبح لها شكلا خاصا بها كما كان مهنما كيفية بدا الخلية الو احدة لعملية الإنشطار لتكون منطابقة مع كافة التغيرات الحيوية ، وتوحي الخلية ان النظام البنائي قائم علي وحدات مركبه وهذه عملية منوفرة في الأغشية البيولوجية وهذه المركبات مكونه غالبا من فراغات وبروتونات اللذان يثكلان حدود خارجية للخلايا حيث إن التركيب الأساس داخل الخلايا و الغثاء المزدوج و الطبقات المفرغة غشاء مكون من فر اغات فقط وطبقة المزدوجة الفارغة هي

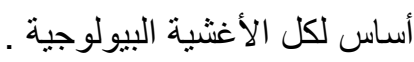
وتتضح العلاقات الثكلية والتركيبية أيضا من حروف الجينات الأربعة عن طريق الثفرة الور اثية للبروتين حيث تتضح العلاقة بين شكل لغة المادة الور اثية ولغة التشكل حيث ظهر مفهوم (DNA) الدانا الذي يتحكم في شكل المخلوقات من خلال آلية معقدة للاختلافات الخلوية حيث ان جزئ البروتون يمكن ان يمثل جملة تتكون من عدة كلمات وكل كلمة تتكون من عدة حروف فمثلا الإلكترون يتمثل في شكل الدوائر تلف حول البروتون وهو بمقام مركز إلكترون وهذا التشبيه اقرب للواقع اقنع

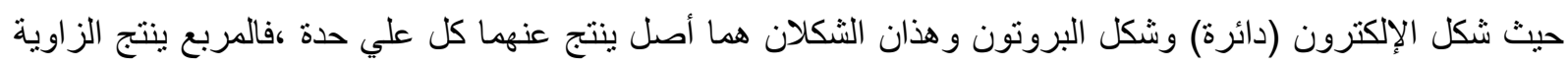
و الزاوية تنتج القوس ، وهذه الأشكال الأربعة هي قاعدة كل الإشكال في المجالات الهندسية والفنية وغير وها في العلوم التطبيقية. وترتبط نظرية المورفوجينيك بالعديد من النظريات العلمية المختلفة والتي يمكن استخدامها في تطوير طريقة التفكير الفني

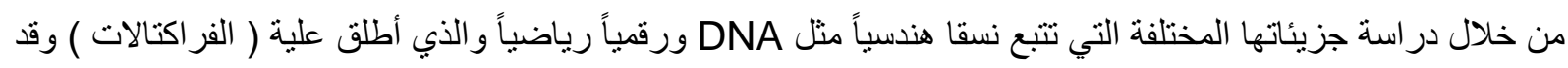
استعان المهندسون المعماريون بعمليات التقسيم المورفوجينيك كما في شكل(3) 

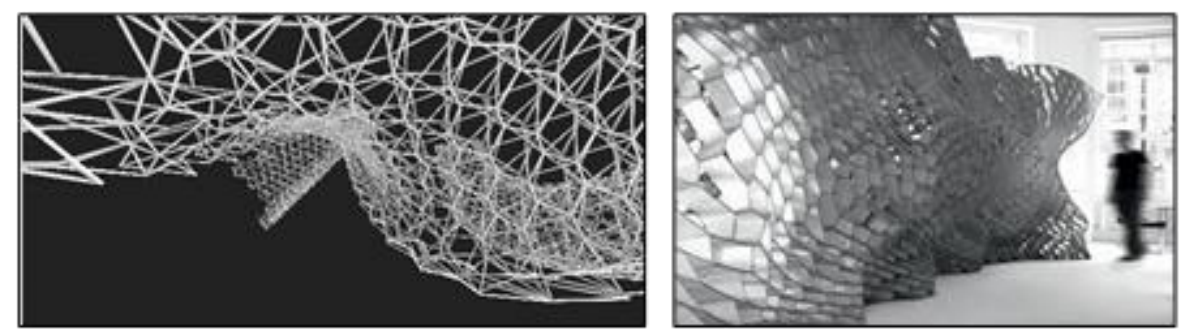

سكل رقم (3) أنماط مختفة من إشكال مجسم المورفوجيني

ويستفاد من النظام المورفوجينيك في تصميم أنتكال متعددة الأبعاد و المستويات ويحدث فيها تر اكب جزئي وتداخل فيما بينها في الفر اغ ونموذج قائم علي شبكات اسطو انية متداخلة تتحرك في الفراغ لبنية داخلية ولها علاقة بالنمو و الاتساع في الحجم

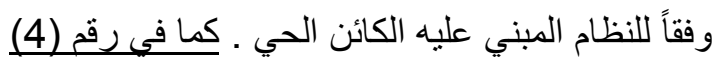
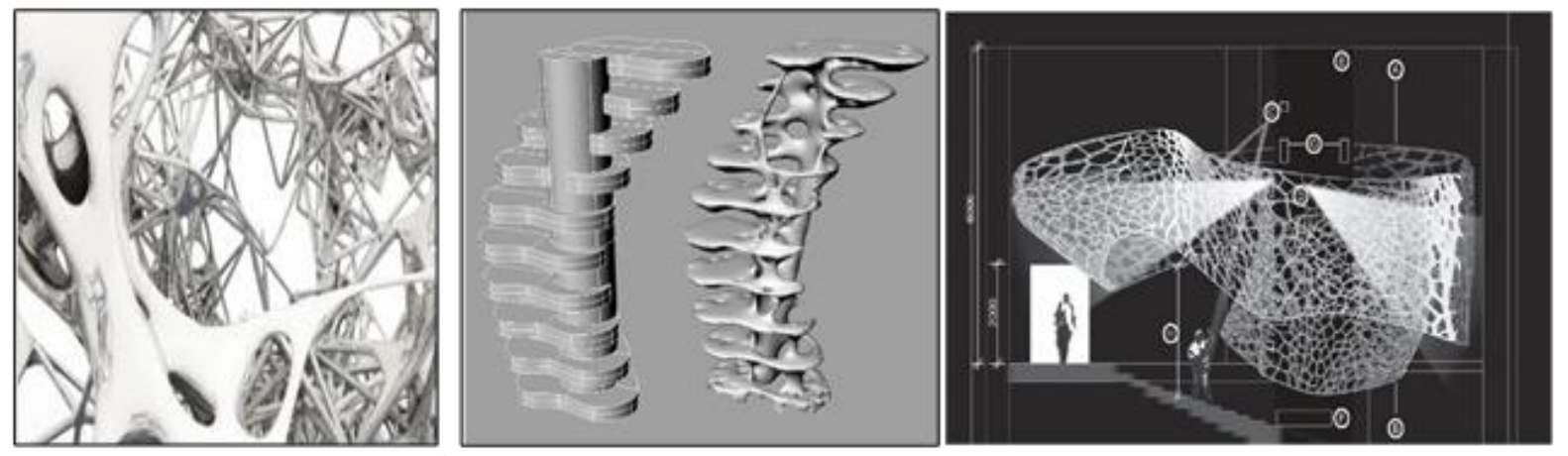

شكل رقم (4) تثكبل ونظم حركية لتعدده الإبعاد و المستويات لها علاقة بالنمو والاتصاع في الحجم وفقاً لنظم المبئي علية الكانت في التصمبم المورفوجينيك

و التكر ار إستر اتيجية أساسية للوجود ، ويتضح التكرار في الخلايا التي نتجت من المركبات البنائية والوظائف المتعددة للخلية و التكرار في الترتيبات البيولوجية لا تعني فقط ان النظام به خلايا اكثر من كل غثاء ، و إنما تترتب تصاعديا للخلايا لكي

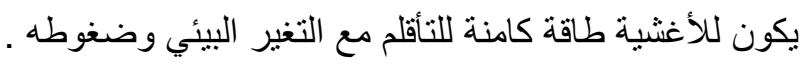
ويعتمد مجال التصميم المورفوجينيك علي إمكانية دراسة الجوهر الداخلي للعناصر العضوية لاستخلاص نظمها الهندسية المجسمة التي تتشكل وفقا لخلاياها ومفرداتها وفقاً لأنظمة معينة تشمل التطبيق القدرة علي التحديد سلسلة مطولة من الثبكات الهندسية التي تسمح بتطبيق التغير , وكذلك تتشكل وفقاً لمفردات تتضمن شروط وهي القدرة علي عمل شفرة ور اثية (كود) أو رمز وممارسة التصنيفات الآخر مما يسمح بالتغيرات في السلوك أو الأرقام للبناء الهندسي. ويتضمن التصميم المورفوجينيك عمليات تحليل لمحتوي جيني او تشكلي متحرك مرتبط بالثبكات الإفتر اضية التي تشكل من خلالها الكائنات الحية ، و هناك علاقة بين التصميمات الزخرفية و التصميم المورفوجينيك يتضمن المفردات كذلك وايضاً كل من الصياغات و المجمو عات اللونية. و الصياغة تتطلب بناء تصميمي تنتظم خلاله المفردات التصميمية فيما يسمي بالثبكات و تختلف أنواع الثبكات ما بين المسطحة و المجسمة والمرنة كما في إعمال الفنانين في النزراث,حيث استخدم الفنان المصري القديم الثبكة في تكبير مفرداتة و واستخدم الفنان الإسلامي مفرداتة وهي نفسها الثبكة ومن الفنانين المعاصرين مثل (فازاريلي) الذي استخدم النظام الرقمي (الديجيتالي) في الثبكية و أيضا الفنان ايشر ومن الفنانين المصريين عبد الرحمن النشار. ويأتي دور (التصميم المورفوجينيك) في تقديمه لنظام شبكي منحرك في الفراغ مرتبط بالنظام المتحرك داخل الجينات. و أهمية هذا البحث في التاكيد علي أهمية البناء التصميمي للثبكات التي تصاغ من خلالها الثعاب المرجانية وبلور ات الثلج ، بما يضفي علية من إيحاء بالتجسيم , حيث يأخذ المصمم من الطبيعة مصادرة لصياغة وتشكيل مفرداتة وبنيته التصميمية 
باستخدام شبكة هندسية مسطحة وثابتة تتظم من خلالها مفردات عضوية مأخوذ من النظام الجيني لإعادة صياغة للاستفادة منه كمدخل جديد معاصر للظواهر الطبيعة في قسم التصميمات الزخرفية في كلية التربية الفنية.

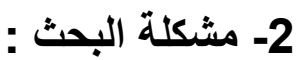

وتعد در اسة التصميم المورفوجينيك للمصدم إمكانية دراسة الجوهر الداخلي للظواهر الطبيعية العضوية مصدراً هاماً للرؤية

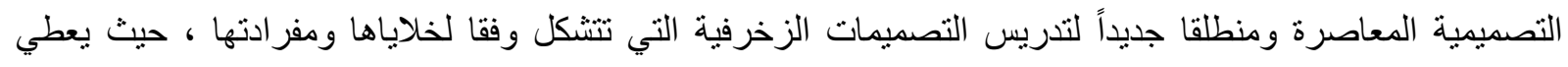
الفرصة للمصدم الزخرفي الاستخدام التصميمات المسطحة والإيحاء بالتجسيم مما يوسع مدارك المصدم الزخرفي في التعامل مع المفردات. من خلال النظرية المورفوجينيك و إثراء عناصر و أسس التصميم بالعديد من المتغيرات التشكيلية عبر توظيفها بالكمبيوتر جر افيك وذللك لتحديث الفكر الخاص بالتصميم الزخرفي في دراسة الظواهر الطبيعية في التصميم والتي أتاحت مجالات غير تقليدية في التصميم المعاصر. ويتحدد سؤال البحث في التساؤل التالي: - إلي أي مدي يستفيد المصمم الزخرفي من التصميم المورفوجينيك وما يستتبعة

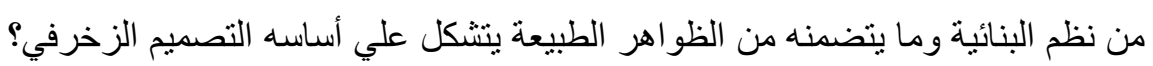

3- أهمية البحث : يتضح أهمية البحث في النقاط الآتية : استحداث حلول تشكيلية متغيرة وذلك إضافة عناصر من الظواهر الطبيعة من خلال فن المورفوجينيك و علاقته بمجال التصميمات الزخرفية للحصول علي صباغة بصرية جديدة تنزن فيها الثبكيات هندسيه والضوء و الألوان والخطوط المتحركة وذللك باستخدام تقنيات متقدمة . إعادة تثكيل وصياغة الحركة الفعلية للظو اهر الطبيعة (الثعاب المرجانية وبلورات الثلج) بما يتفق بالجانب التصميمي الزخرفي.

إثراء مناهج مادة التصميمات الزخرفية وطرق تدريسها لمفهوم يو اكب حركة الفنون المعاصرة بالنظريات العلمية.

\section{4- أهداف البحث: تتحدد أهداف البحث فيما يلي:}

التوظيف الجر افيكي للقيم الحركية للظواهر الطبيعة في فن المورفوجينيك خلال مجموعة من التصميمات الزخرفية. طرح مداخل تجربيبة جديدة لبناء اللوحة الزخرفية في ضوء بنية النظام المورفوجينيك. إنتاج مجموعة من التطبيقات العلمية مستفيدة من التوظيف الجرافيكي للكمبيوتر للمتغيرات الحركية ثنائية الإبعاد (الثعاب المرجانية وبلورات التلج) من خلال فن المورفوجينيك.

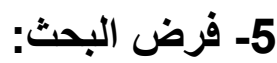
ما إمكانية استفادة المصمم الزخرفي من دراسة التصميم المورفوجينيك ونظمة وصيغة في إثراء تدريس التصميمات الزخرفية. 
6- منهجية البحث: يستخدم البحث منهجين من مناهج البحث في هذه الدراسة:

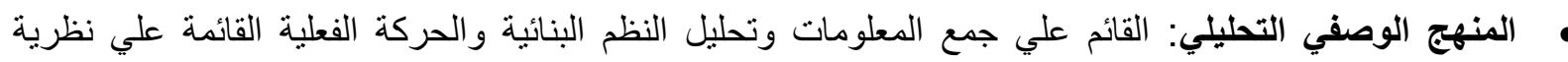
المورفوجينيك لاستخلاص الدفردات و النظام البنائي والمجموعة اللونية و هذا فيما ينعلق بالإطار النظري للار استة وتوظيفها بالتقنيات الحديثة في التصميمات الزخرفية باستخدام الكمبيوتر.

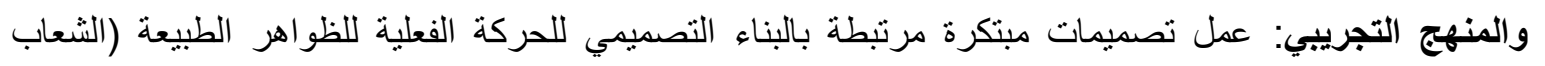

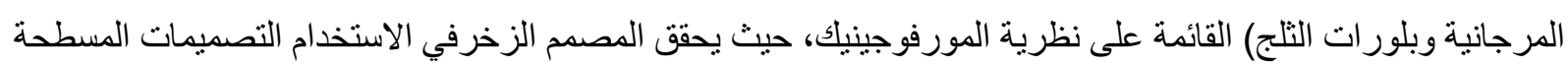

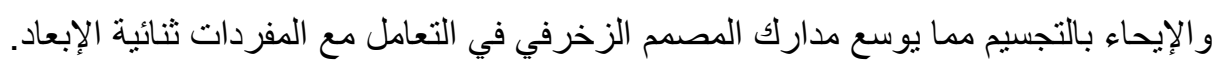

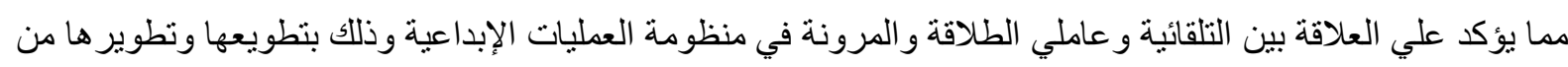

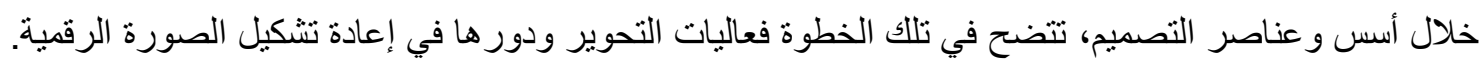

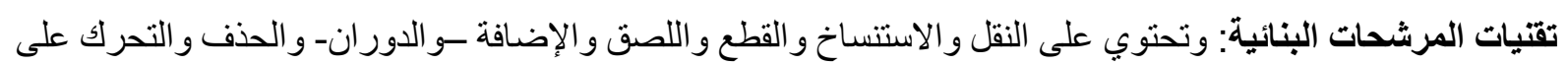

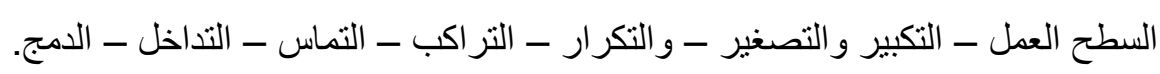

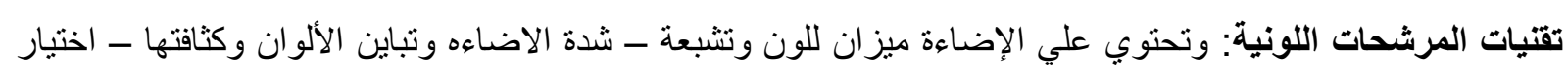

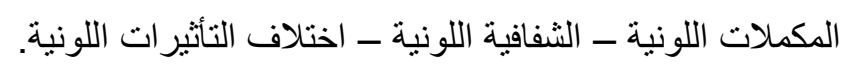
7- موضوع البحث: مصطلحات البحث:

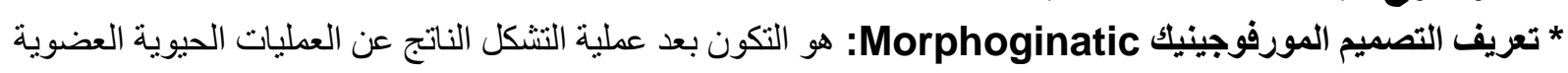

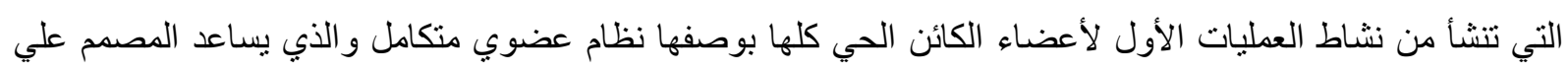

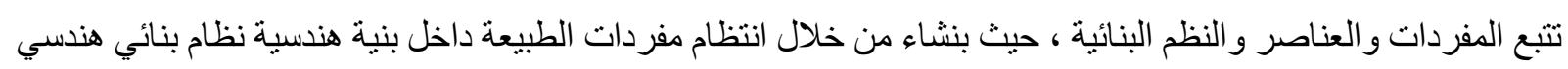

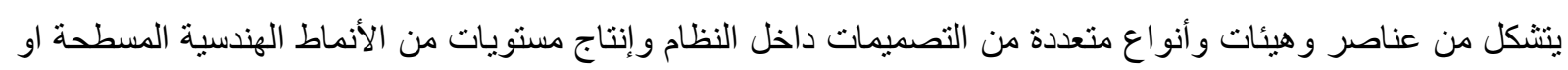

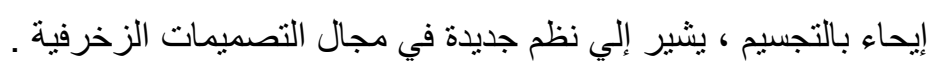

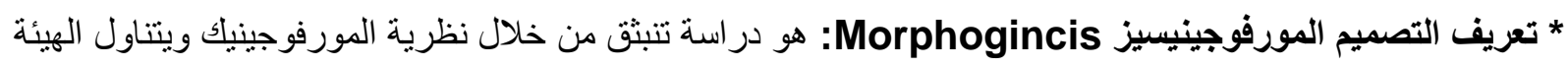

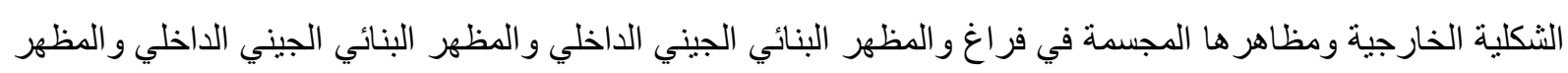

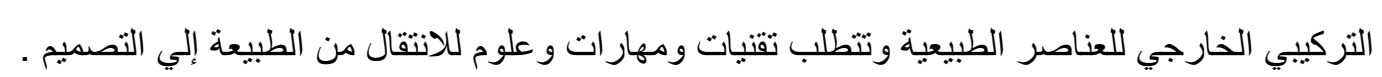

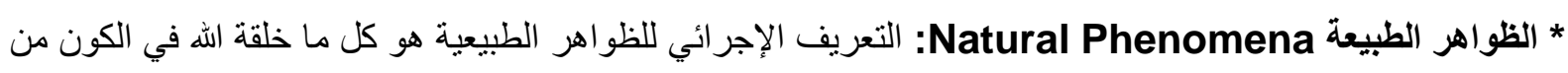

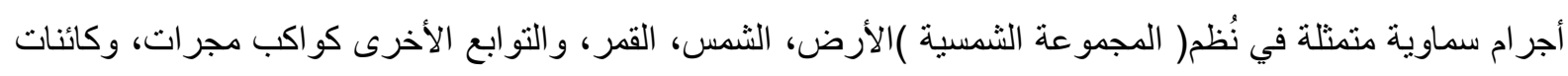

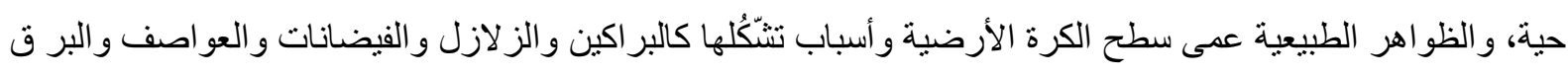

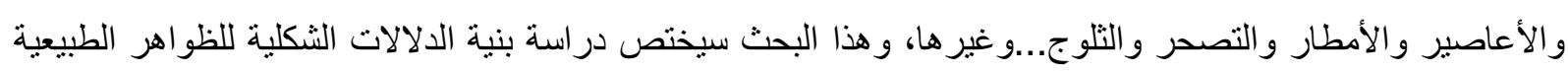

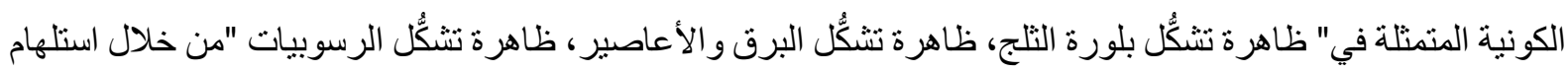

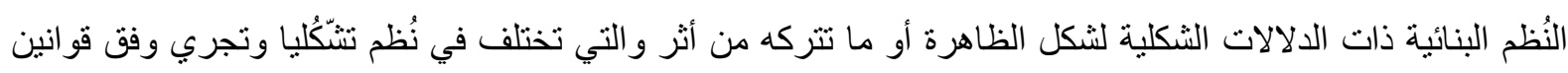

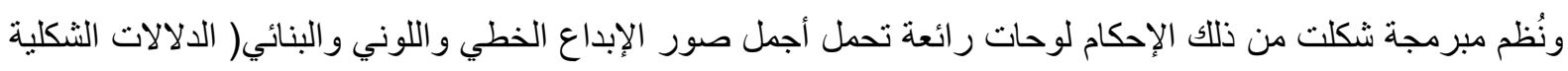

$$
\text { ) ومحاولة إكسابها فلسفات عملية ورؤية فنية معاصرة. }
$$

* تعريف الفن الحيوي Bio Art: هو علم الدراسات العضوية النانئة عن نثاط أعضاء الكائن الحي بوصفها نثاط

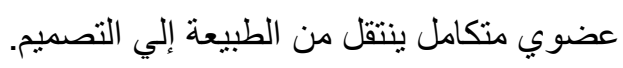
* تعريف البنية Structure : وهو ديناميكية التككف من خلال استمر ارية عمل النظام حيث يبقي البناء الأساسي دون تحكم خارجي ولا يتعارض مع القوي الخارجية وهو نظام طبيعي ( فيزيائي ). 
التعريف الإجرائي ليا في هذه الدراسة ، يقصد بالبُنية في هذا البحث النُظم التركيبية التكوينية لعناصر الظواهر الطبيعية و القو انين الخلقية و الإنثائية لها.

ه وتدور محاور هذا البحث حول عدة مداخل بحثية علي النحو التالي:

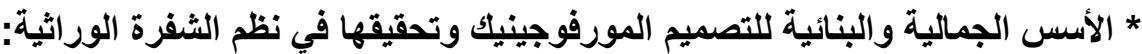

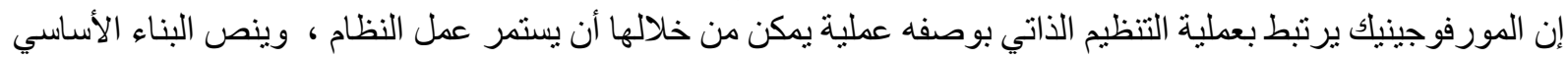
دون تحكم خارجي الذي لم يعوق القوي الخارجية حيث كانت الأنظمة الفيزيائية (الطبيعية) موجودة داخل بيئة علماء الطبيعة. ومفهوم الطبيعة لدي المصدم يتغير تبعاً لثقافة العصر ونتيجة لاكتشافات العلمية ، فلم يعد قاصر اً علي المظاهر الخارجية

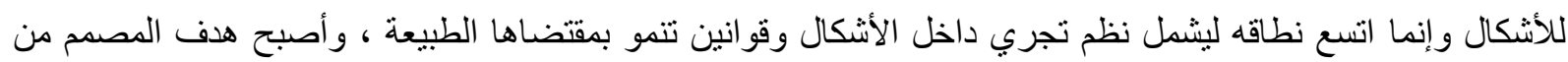
دراسة عناصر الطبيعة أكثر عمقاً وتتوعاً مما أتاح المجال لرؤية جديدة كان لها أثر واضح في تنوع الإتتاج الفني،ومفهوم الطبيعة لدي المصدم يتغير تبعاً لثقافة العصر ونتيجة للاكتشاف العلمية ، فلم يعد قاصر اً علي المظاهر الخارجية للأشكال ، و إنما اتسع نطاقه ليشمل أنظمة محددة نجري داخل الأشكال وقوانين تتمو بمقتضاها الطبيعة ، و أصبح هدف المصمم من دراسة عناصر الطبيعة التعرف علي النظم والتراكيب والقوانين التي تختفي وراء المظهر الخارجي ، ويؤكد هريرت ريد هذا بقوله : تلك القو انين بصور ها المتعددة تتحكم في نمو سائر الكائنات الحية ، وجمع أنواع النباتات والأزهار و الثمار ، بل إنها كائنة في أدق الخلايا وجزيئات المادة. ومع اكتشاف القو انين التي تحكم التوراث وفلك الثفرة الكيمائية لفن المورفوجينيك التي تكتب بها وحدات التوارث بدأت حركة فنية جديدة تسمي "الفن الحيوي Bio Art" وتعتبر هذه الحركة الجسر الواصل بين علم الور اثية و الفن التشكيلي .فالفن الحيوي Bio Art ممارسة الفن وإنتاج أعمال فنية داخل المختبر أو داخل استوديوهات المصممين باستخدامات أدوات التكنولوجيا الحيوية والتي تشمل مجالات مثل الهندسة الور اثية وزر اعة الأنسجة والاستنساخ والعناصر التي يستخدمها المصمم ، هي خلايا الحمض النووي "DNA" و البروتينات و الأنسجة التحتية ، وتخليق الكائنات الحية وتطبيقاتها في علوم الحياة الجمالية والفنية والاجتماعية . و الفن الحيوي Bio Art هو فن جديد نشأ عن الأثر الثقافي وزيادة إمكانية الحصول علي التكنولوجيا الحيوية المعاصرة ، وهو الفن الذي يستخدم التكنولوجيا الحيوية وتحديد ومناقثة الآثار المترتبة علي العلوم النظرية والتاريخية والبيولوجية و الفنية ،فالفن الحيوي يمكن من خلاله التلاعب في عمليات الحياة في اختراع او تحول الكائنات الحية , وتعتبر "الفن الحيوي لهيل "Bio Art" أطلقه "ادوار كاك Eduardo Kac" في عام 1997 و علي الرغم من أن هذا الفن نشأ في نهاية القرن العشرين إلا أن الفن الحيوي Bio Art لم يمارس علي نطاق و اسع إلا في بداية القرن الواحد و العشرين ولذلك تعتبر بداية هذه الحركة

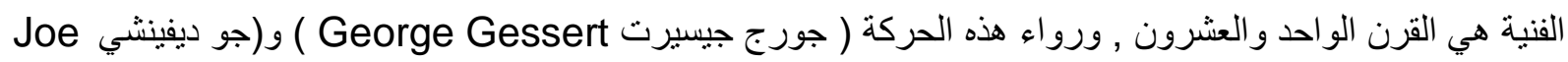

(Pavis) و (ادوار كالك (Eduardo Kac). فقد اهتموا بنطوير العمل الذي يسمي ( الفنون البحتية و الفنون الحيوية ) الذي استمد موضوعة من الكائنات الحية إلي فن جديد يقوم علي استخدام تقنيات الهندسة الور اثية لتخلق أعمال جديدة قائمة علي الخلايا الحية و الثريط الور اثة ( الجينوم).

\section{أولا: النظم البنائية للثفرة الوراثية لفن المورفوجينيك:}

" لقد بنيت الطبيعة وفقاً لمبادئ علمية تظهر من خلال مختلف الإشكال و الحركات ويحكمها التناسق بصور مختلفة في جميع تكوينات الطبيعة ويرنكز هذا التناسق علي قواعد الثكل و التي تنزامن مع قو انين الهندسة ، وبينما تقوم الهندسة بناء الأشكال بأسلوب تجريدي ، وتعد النظم التنكيلية مثالاً للهندسة الحية حيث ترتكز جميع النواتج علي قو انين هندسية تحكم بناءها" ـ. 
و الكثف عن القو انين البنائية المستترة داخل مادة الثفرة الور اثية و التي تكونت بمقتضاها وما تحتويه علي قوانين لجوهر

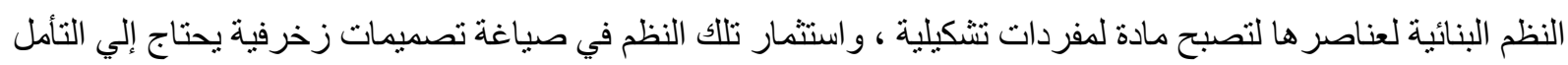

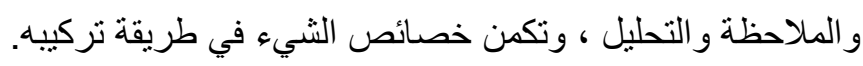
إن الإشكال العضوية كأحد الأشكال الطبيعية تخضع للعديد من العوامل التركيبية التي تتحكم في بنية تلك الأشكال وهيئاتها ومن هذه العو امل التركيبة : التنوع ،التوازن التماسك ، الانتظام ، الإدراك ويتضح ذلك بشكل واضح في نمو الخلايا وجزيئات المادة الور اثية ذلك أن تلك المظاهر عبارة عن انعكاس لمنطق داخلي يترجم نظم الطبيعة إلي قو انين بنائية كامنة

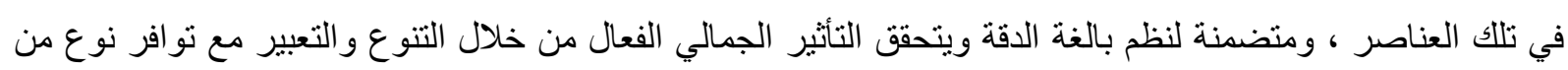
النظام و الوحدة للربط بين العناصر بشكل قوي يحكم النظام. فالنظم البيئية في الثفرة الور اثية هندسية وشكلية تخضع في نموها لمهارات محددة في علاقات شكلية أو من حيث البناء الهندسي كمنطلق لاستخلاص جو هر النظام في تلك العلاقات الثكلية.

\section{ثانياً : نظم الثفرة الوراثية لفن المورفوجينيك:}

تكمن الثفرة الور اثثة لفن المورفوجنيك في الكورموسومات ، و هي عبارة عن خيوط طويلة مجدولة الثونة تتألف من حامض الدي

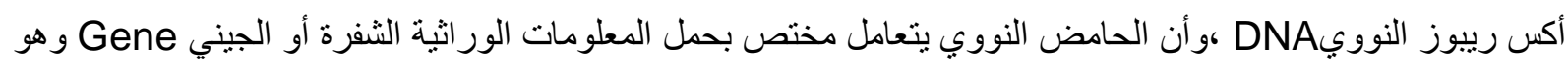
جزء من DNA وللجينات لغة تخاطب من DNA تعمل كمنظم لعمل الجينر تعرف بالجينات المنظمة وان لغة الجينات تتألف من أربعة حروف هي A.C.T.G السابق ذكر ها أما كلماتها فتتألف من ثنلاث حروف فقط من تلأك الحروف الاربعة

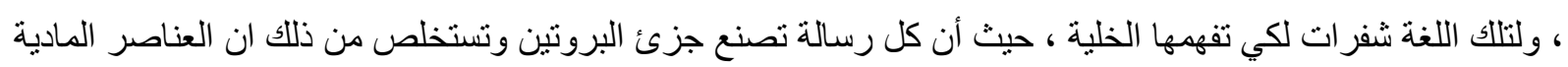
للثفرة الور اثية هي ( الكرموسومات و حامض الدي أكس رييوز النووي لئنNA و الجينات و البروتينات). أ- النظام الخطي للشفرة الوراثية لفن المورفوجينيك :

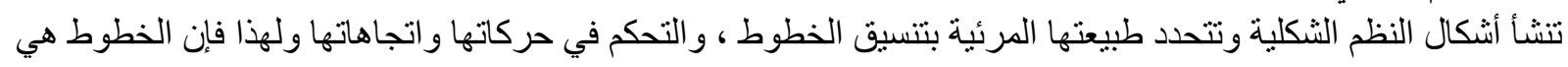

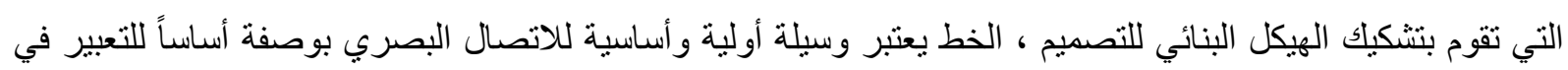

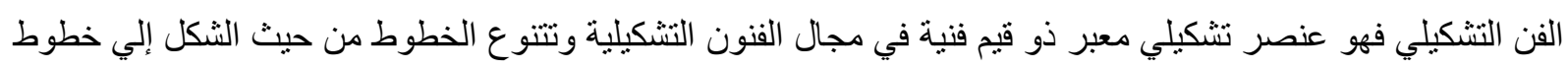
هندسية وخطوط حرة وتتتج الخطوط الهندسية باستخدام أدوات الهندسية أو الخطوط الحرة فهي غير منتظمة وتتسم بالتلقائية ، و الخط له قيمته الثكلية ودلالاته التي بها بشكل المحتوي فالنظم الخطية في مادة الثفرة الور اثنية متنوعة بين الخطوط

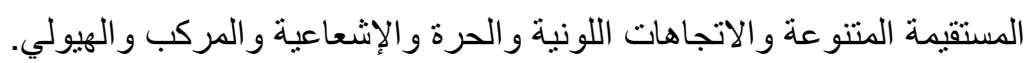

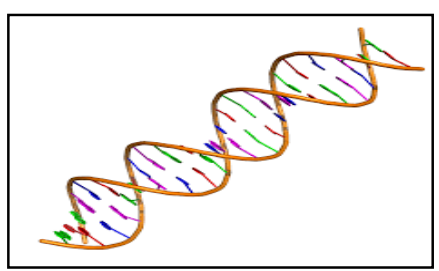

DNA مل (5) نموذج للولبي في مادة

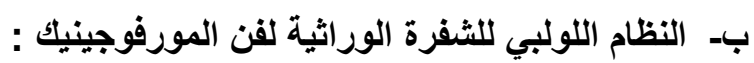

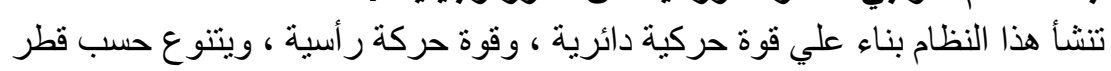

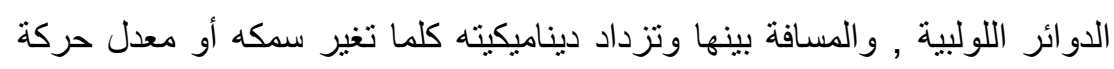
الدوران الر أسي ، ويتحرك الثريط الور اثي بشكل تنازلي ونوحي هذه الخطوط بأثنكال

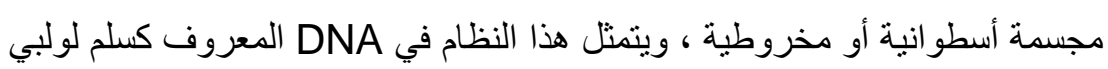

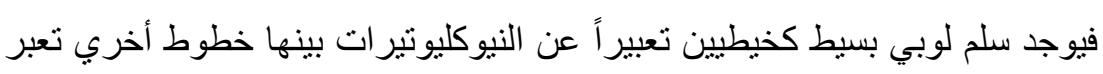
عن الأواصر الهيدروجينية ومجدولين كما يتجادل الصغيرة وكل هذه الصور صور تخطيطية مستوحاة من الافتر اض الذي لئي افتراضه العالمان واستوت كريك بأن جميع ال DNA موجود بشكل لولب مزدوج و علي نموذج و استون دكريك و الذي 
يستتد علي نماذج انكسار الأشعة المبنية X-Ray Diffraction الناتجة عن ألياف الDNA المعزولة تحتوي علي جزئيات

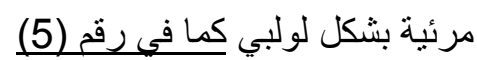

ت- النظم الخطية المركبة للشفرة الوراثية لفن المورفوجينيك : قد يكون أساسها الخط المستقيم أو الخط غير المستقيم وفيها الخط المتعرج و الخط الحلزوني و الخط المموج و الخط اللولبي

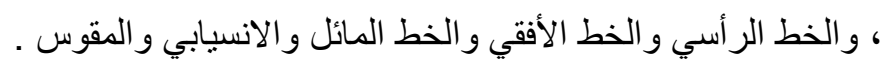
وقد تجمع بين أكثر من نوع بين نفس الثكل وتشمل النظم الخطية المركبة في مادة الثفرة الور اثية في صور مأخوذة من الدر اسات لخيوط الDNA بوسائل مختلفة كتأثير الأشعة أو بتحليلها.

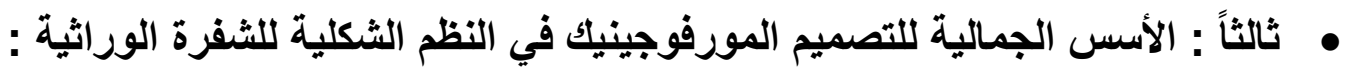
إن النظم البنائية في الأشكال في الطبيعة تأخذ نظاماً يمكن من خلاله تتبع منطق التركيب و الذبي يتضح من خلال التئه التنوع الكبير بين عناصر الطبيعة بعضها البعض ، وبين مفردات العنصر الواحد ، والذي يتأثر في تتكيلة العوامل البيئية المحيطة به ، فالطبيعة في تتو عها هذا يتجنب الكائنات كل ما يثير الملل . وهي في ذللك تقدم المصمم قيماً جمالية كالاتزان والتناسب و التناغم والوحدة بين الأجزاء من أجل دفع إدراكه وتوجيهه

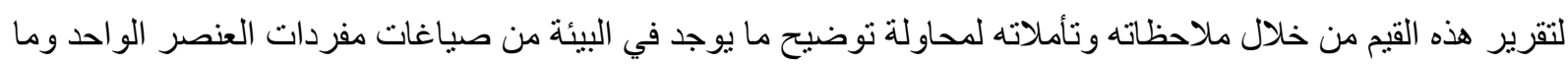

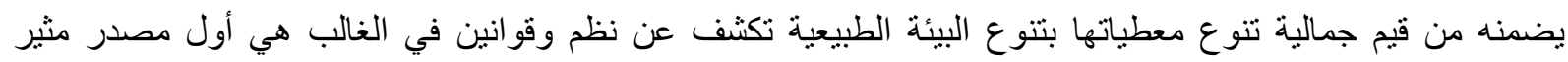

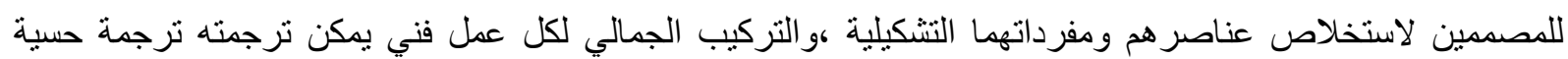
وجدانية للنظم التي يستشعر ها المصمم من علاقة بيئية يمكن إدر الك الطبيعة وتفهم الأسس و القو انين العامة التي تحكم أشكالها ونسبها فمن خلالها يمكن إيجاد مقاييس لنظم ونسق الثكل في الطبيعة و التي يمكن الاهنداء بها كمنطق في النركيب الإعمال

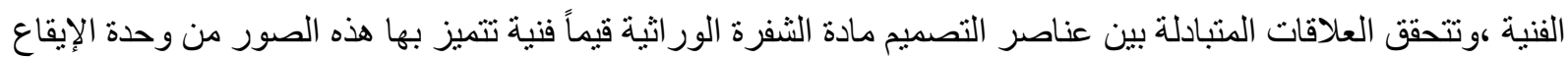

و الاتزان و التكر ار و التدرج و التنوع و التماتل كما في رقم (6).
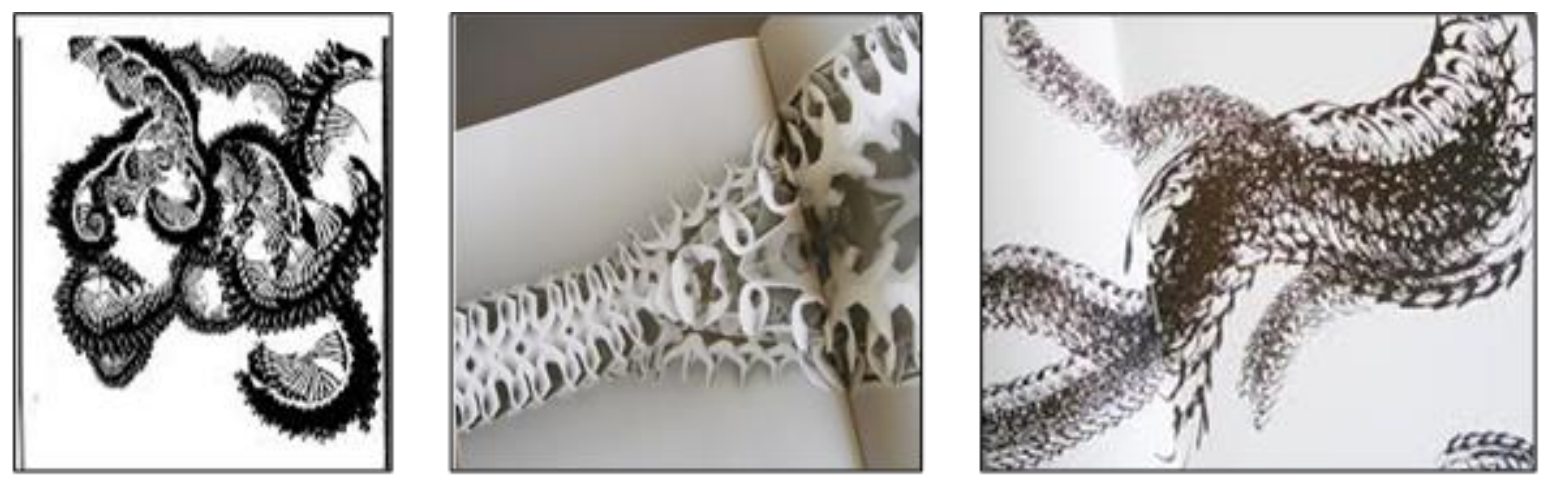

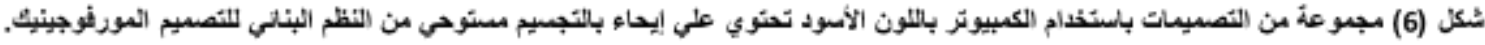

\section{• رابعاً: علاقة الثكل في الظواهر الطبيعية بالبنية التصميم المورفوجينيك:}

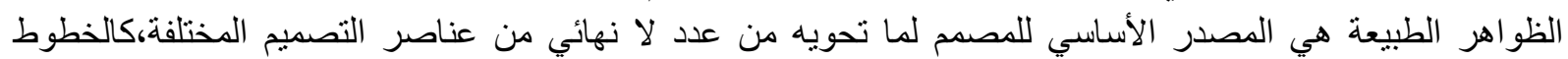

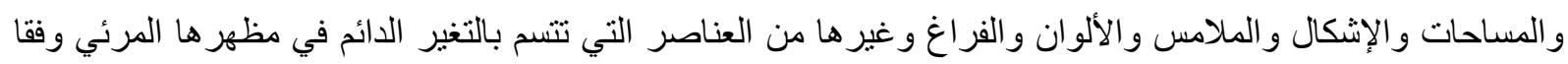
لما يحدث في الطبيعة من متغيرات ، ورغم ذلك يطر أ علي هذه العناصر متغيرات إلا أنه يحكمها قانون الطبيعة للنمو ،فالكائنات الحية جميعها يحكمها القانون الطبيعي للنمو مما يصعب حصر هذا القانون ،كما يعكس أيضاً نظاماً مرئياً متكاملاً يستخلص منه المصمم ليعبر عنه برؤيته الخاصة ووسائل الأدائية تصميماته المستوحاة من الطبيعة ، فالإنسان بطبعة إلي 
النظام ، وهذا يبعث في ذهنه نوعاً من الارنباح ، فمنذ نشأته الأولي بسعي دائماً إلي النظام في مختلف مظاهر حياته ، فيستخدم قدراته الابتكارية في تفهم العلاقات المختلفة من الظواهر الكونية الموجودة حوله ، كما يكتب عادات الترتيب و التصنيف و التنسيق بين الموجودات ثم يحاول الاستفادة منه ، فعناصر الطبيعة يحكمها قانون طبيعي للنمو ،فبالر غم من أنه من الصعب أن يتطابق عنصر إن من فصيلة واحدة إلا أنه قد تثابه في هيئتها الخارجية ، ومن خلال تأملات المصمم الدقيقة

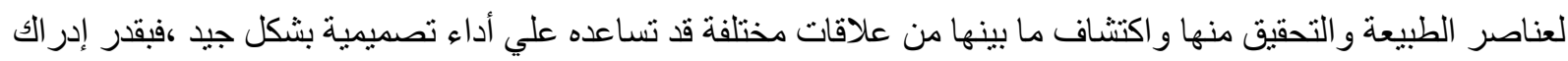
ووعي المصدم لهذه العلاقات ، و إمكانية الاستفادة منها وإعادة صياغتها فإن ذلك يساعده في إيجاد الحلول التصميمية

المبتكرة. إن علاقة الثكل بالظو اهر الطبيعية بالبنية هي كل ما يمكن رؤيته في العمل الفني وذللك يتضح من خلال عناصر التصميم

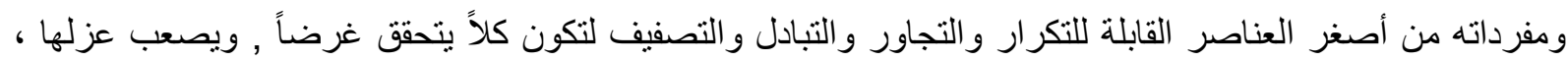
ولكن يمكن فصلها للار اسة و التعرف عليها و علي القوي الكافية بها و علي ما يمكن أن تحققه في العمل الفني ، وهي مفردات لغة الثكل الني يستخدمها الفنان و المصمح. وتستمد عن طريق المتغيرات من خلال المرور بالتجربة والمواقف الجمالية في الطبيعة وتأملها وفحصها ، فالعناصر الأولية المرئية لأشكال الطبيعة هي ذاتها العناصر الأولية للتصميم ،فالنقطة والخط و الثكل و الحجم والفر اغ و الملمس واللون،هي ولهي في جو هر ها مثير ات فيزيائية لحاسة البصر تنشأ عن تفاعل الضوء مع مادة الثكل فباختلاف تبايناتها الثكلية بداء من النقطة حتي الحجم فتحقيقها الجو هرية انعكاسات ضوئية منباينة كيفاً وكما ، فالثكل هو أحد العناصر الأساسية في التصميم و العنصر

يمكن تعريفه أيضا في ضوء نظرية النظم بأنه نظام متكامل يتحدد هويته نتيجة لفاعلية العلاقة التبادلية بين العناصر المكونة له ، وقد ميز أفلاطون بين الثكل النسبي و الثكل المطلق ، فالثكل النسبي هو الثكل الذي كانت نسبة أو جمالة موروث في طبيعة الأشياء الحية ،وفي طبعة الصور المقلدة للأشياء الحية ، اما الثكل المطلق فهو الذي يتمثل في الصورة أو التجريد الذي يعتمد علي الخطوط المستقيمة أو المنحنية والسطوح و الأشكال الطلبة التي تستخرج من قبل هذه الأشياء الحية, ويوجد من الإشكال الناجمة ما بسمي بالثكل البنائي أو الهندسي او الثكل الرمزي أو المجرد أو المطلق , ويمكن أن تفرق بين

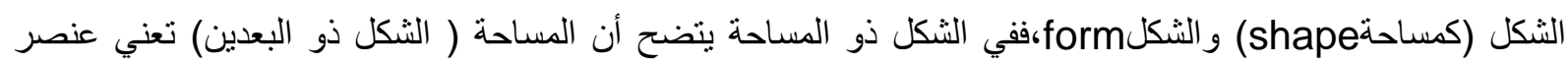
مسطح أولي اكثر تركيباً من النقطة والخط ، متبعاً للتعريف الهندسي ينشأ الثكل من تتابع مجمو عة متجاورة ومتلاحقة من الخطوط، حيث يؤدي التتابع إلي تكون مساحة متجانسة تختلف مظهر الحدود الخارجية لها باختلاف تكوين الخط الذي ينشأ

$$
\text { عن تكر اره وباختلاف اتجاه ونظام متحركة. }
$$

أما الثكل ككتلة فينشأ عن تحركه المساحة المستوية في اتجاه مخالف لاتجاهه الذاتي ويشكل حجم التكوين ، وله طول وعرض و عمق ( الثكل ذو الثلاثة أبعاد) وليس له وزن ويحدد بمقدار الحيز الذي يشغله من الفراغ. وتصنف الأشكال في الطبيعة كأشكال عضوية أو هندسية فالإشكال العضوية هي التي تعطي انطباعا بوجود الصفات الحيوية التي تميز الكائنات الحية فهي إنكال ذات صله و اضحة بعناصر الطبيعة . كما في عنصر الخط في مادة الثفرة الور اثثة بشكل حلزوني في الثريط الور اثي DNA او خط منحني ملتف عشو ائيا في

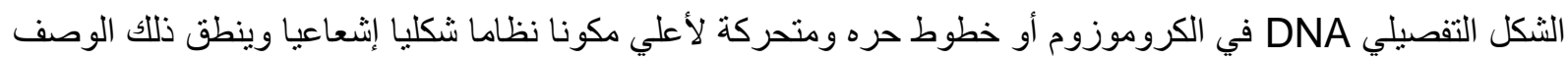
علي عناصر التصميم الاخري ، وتكون تلك المكونات الأساسية لأي تصميم ولتنظيم نظام شكلي ذو فاعلية.

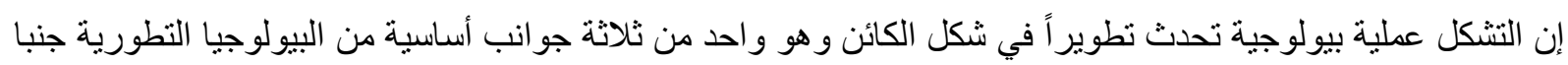
إلي جنب مع السيطرة علي نمو الخلايا والتمايز الخلوي ،وتسيطر علي عملية التوزيع المكاني المنظم الخلايا أثناء التطور 
الجنيني للكائن ، هذا ويمكن أن يحدث أيضاً في ثقافة الخلية أو داخل الخلايا ، كما يصف التنكل أيضاً تطوير وحيدة أثنكال الحياة التي ليس لديها مرحلة جنينية في دورة حياتها او يصف تطور هيكل الجسم في خلال مجموعة تصنيفية.

أ - المورفوجينيك في الظواهر الطبيعة: تعتبر الظواهر الطبيعية موضوعاً لاهنمام العديد مي مجالات البحث العلمي ومنها مجال البحث في تنظير الفن والتربية الفنية حيث الكثف عن الإسرار الكامنة خلف جماليات الطبيعة بكل ما تحمله من دوافع داخلية ومؤثرات خارجية أدت لتشكيلها بالصورة التي وجدت عليها ـو هذا الأساس القائم عليه البحث, الكثف عف دقة النظام التركيبي الخطي للطبيعة العضوية و الغير عضوية ودر اسة نمو ها وتتشكُلها من الناحية الفنية. و هذا النظام الحركي العام يكون أحد المداخل التصميمية في الفنون التشكيلية عامة وتحديداً تصميمات الزخرفية المعاصرة

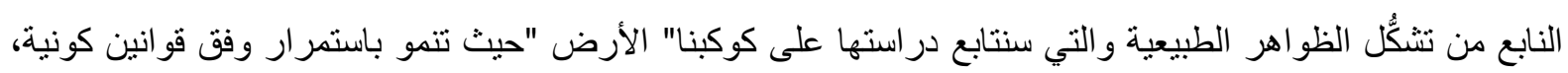
تتشكّل بصورة بيولوجية ونظام هندسي معين، يتغير نظاميا التشكلي بوجود مؤثرات خارجية ودو افع أدت لنخلخل نظامها

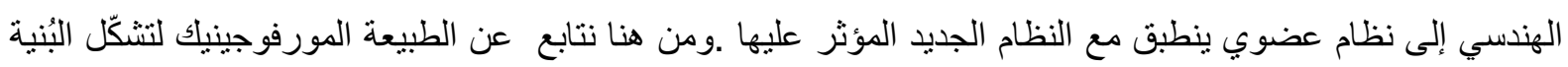
الدلالية للظو اهر الطبيعية عمى كوكبنا" الأرض .حيث تتابع طبيعة هذه الظو اهر ابتداءً من أساس تشكُلها التي أساسيا الدورة

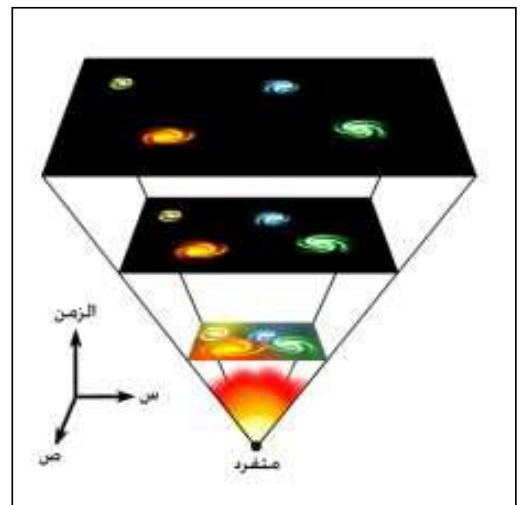

شكل (7) يوضح النظام المورفوجينيك لاتساع الكون وتباع المجرات

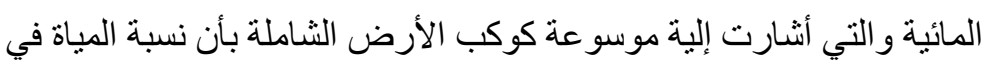

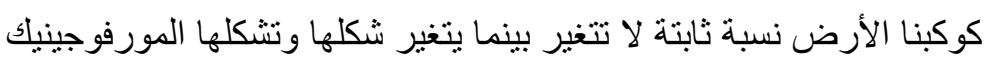

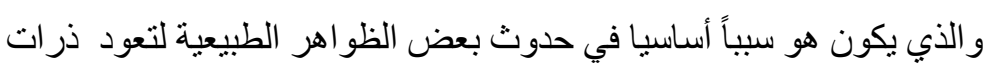
الماء مرة أخري لموطنها سطح الأرض وهكذا نتابع دورتها الطبيعية في التشكل وتشكيل الظواهر الطبيعية في كوكب الأرض.

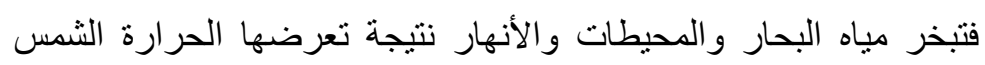

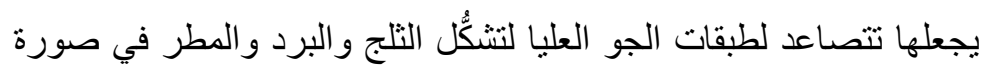
سحب رقمية وتفريغ شحناتها الكهربائية في صورة البرق والرعد والصو اعق إثر تحريك الرياح لها و العو اصف والأعاصير ...وما إلى ذلك . و هنالك مسببات و أنماط شكّلت بنيها بالصور التي تظهر عليها وكما شكل رقم(7).

ب- المورفوجينيك داخل بلورات الثبج: التلج أحد الظو اهر الطبيعية في الكون ويتشكّل بصورة بيولوجية في كوكبنا ما بين الأرض و السماء ويعتبر نوعاً من أنواع الهطول على شكل بلورات دقيقة جد اً من ذرات بخار الماء المتجمدة وعّرفها( الفهاد وقرم) (2005) في أبسط معانيها

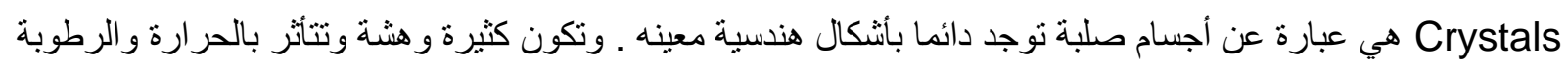

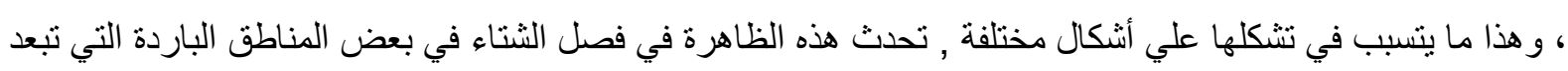
عن خط الاستواء وتزداد غز ارة الثلوج وكثافتها كلما اتجهنا قريبا من القطبين الجنوبي و الثمالي.

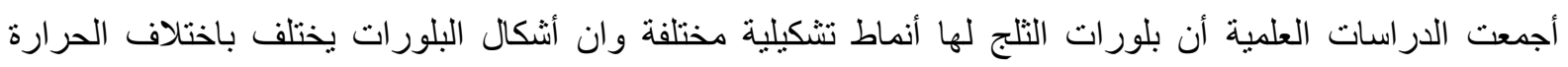
والرطوبة، وهذا ما أكده الكحيل(د ـت ) أن جزئيات الماء عند تجمدها ورؤيتها من تحت المجهر الإلكتروني نلاحظ أنها تظهر بأثكال مختلفة بل إنه لا توجد أي جزيئة ماء تثبه الأخرى ! و هذا يدل علي وحدانية الخالق سبحانه وتعالى؛ فجميع

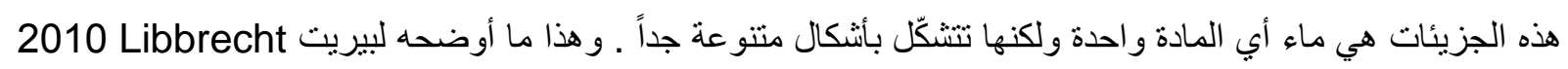

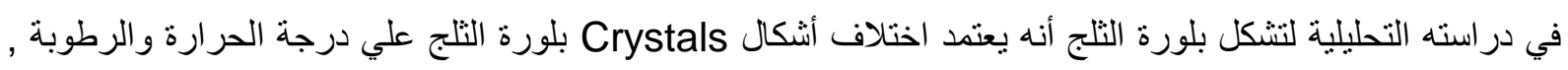

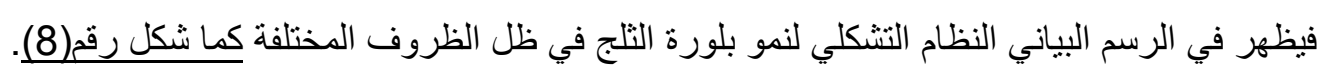


حيث يظهر تشكل البلورات رقيقاً في جميع الاتجاهات إضافة إلي كون إثكالها بسيطة عندما تكون درجة الحرارة و الرطوبة منخفضة ،في حين تظهر بلورة التلج أسمك وينمو حجمها عضوياً في جميع الاتجاهات إضافة إلي كون أنثكالها أكثر تعقيداً

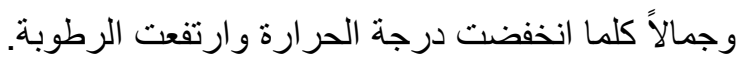

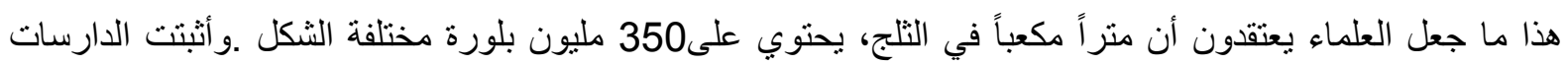

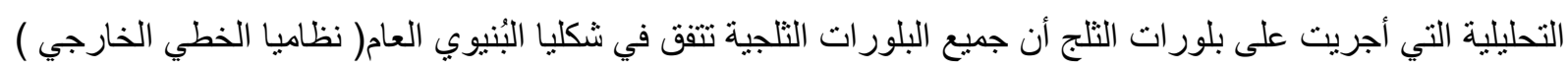
بانتظامها عمى بُنية الثكل الهندسي السداسي، إلا أنيا تختلف بُنية نشكلها الداخلية فهي مرتبة ومنظمة بتناسق و إبداع فيما

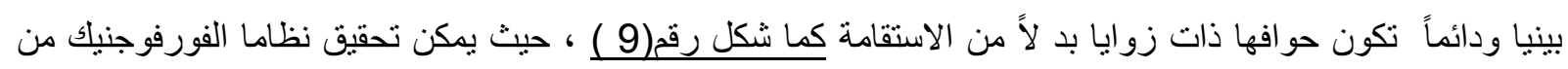

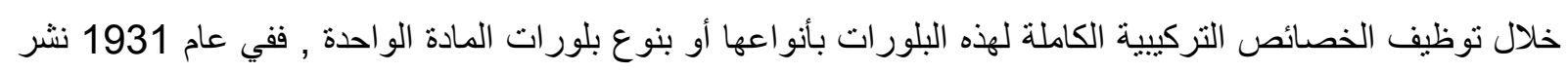

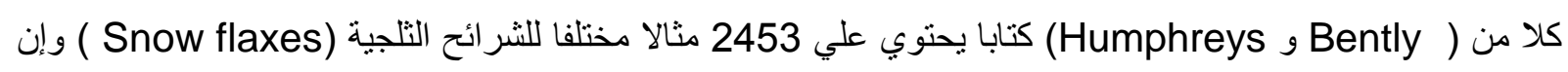
كان لا يمكن رؤيتها الإ تحت المجهر إلا أن لها العديد من الهيئات البنائية الهندسية المنظمة التي تجمعها في قاعدة الوحدة
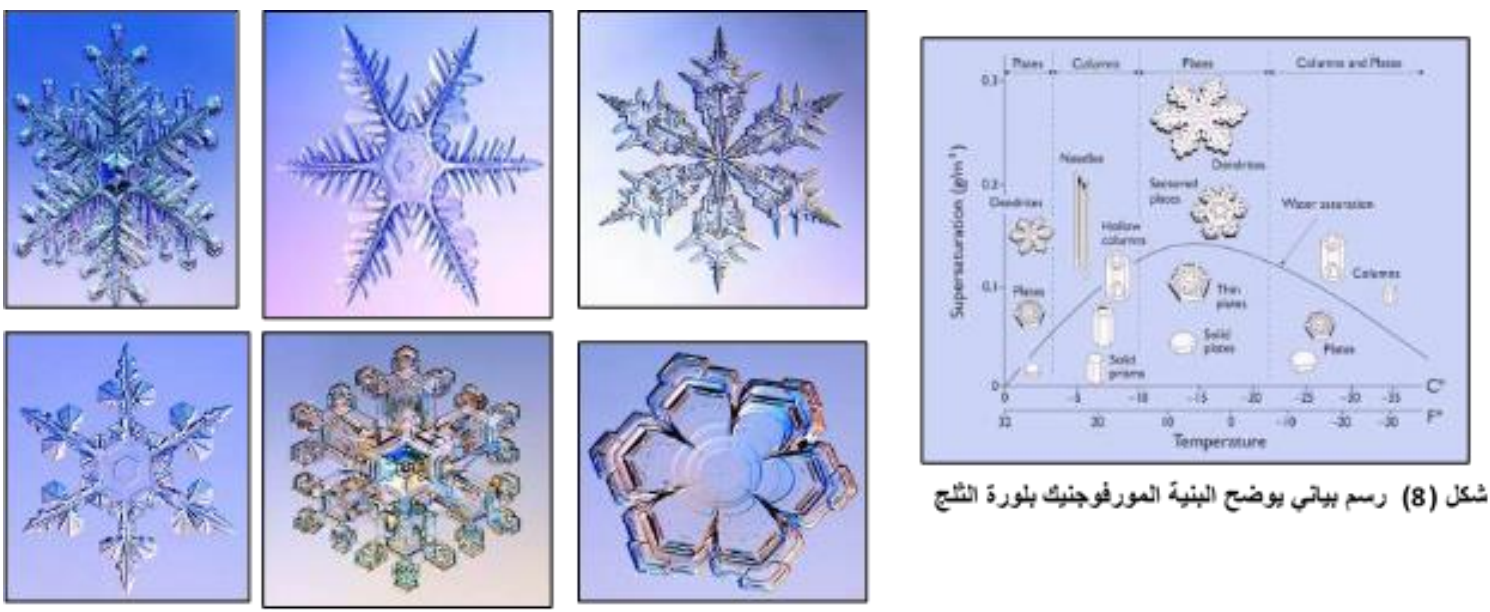

شكل (9) يوضح نماذج مختفة لمئبية المورفولوجية لتثكُل مجموعة من البلورات الثلجبة

تُكَت وفق نظام هنسي (سنسي)

والتنوع.

والأساس الهندسي التي تشترك فيه تلك البلورات هو الثكل السداسي المتصلة أقطاره و المنقاطعة مع بعضها البعض في

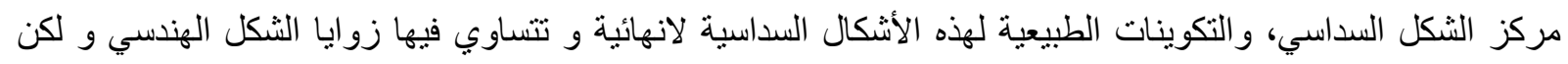

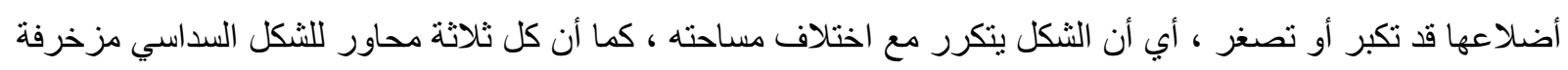
ومفصله وهي تختلف من بلورة لآخري , و لكن تلك البلورات تعطي الدليل المرئي للنظام الثبكي في الفراغ من خدان خلال بتائياتها المحدة ،ويعتمد الجمال في بلور ات التلج علي نظامها الرياضي وتثابهها ، وتر ابط أعداد متنو عة من شكل و واحد ،

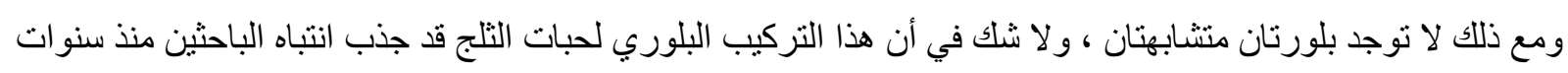

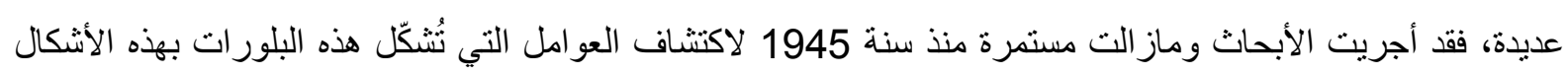

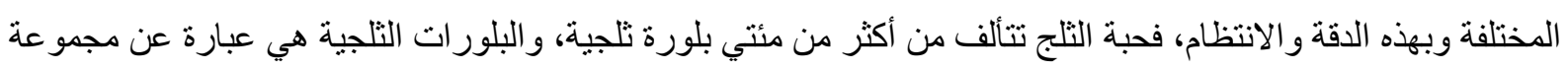

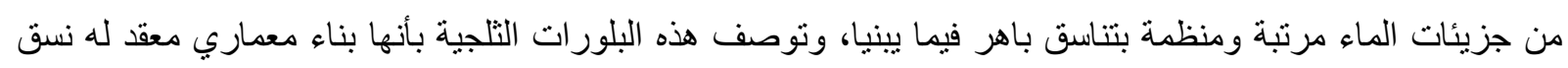
منظم بدأ بالتشكّل عندما مر بخار الماء خلال السحاب متعرضاء ونسا للبرودة. 
ومن هنا يوجد ثلاث أنواع من أشكال البلورات حسب أوجهها وهي :

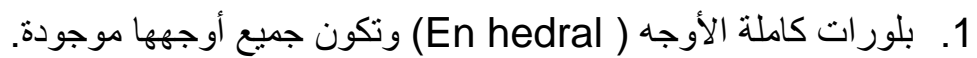

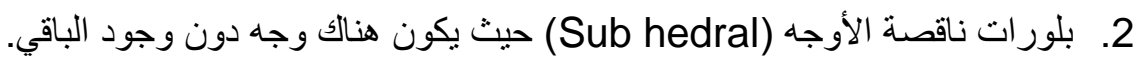
3. بلورات عديمة الأوجه (An hedral) حيث يكون المادة المتبلورة عبارة عن حبيبات لا يحدها أي أوجه بلورية . ج- المورفوجينيك داخل الشعب المرجانية: تشكل الشعاب المرجانية باتجاه الرياح عملية ديناميكية يتم التحكم فيها بشكل مباشر من خلال إمكانات نمو الثعاب المرجانية

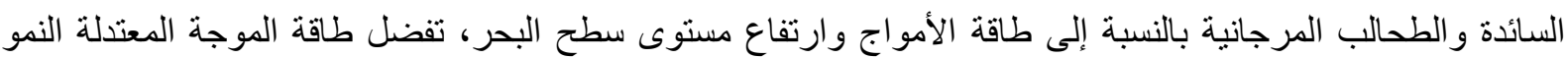
الرأسي السريع الذي يكون مساميًا وغير منطور ؛ تفضل طاقة الموجة العالية النمو البطيء ولكن المضغوط ـون من المحتمل أن تكون إمكانات النمو في الثعاب المرجانية في منطقة البحر الكاريبي والهند و المحيط الهادئ متكافئة .ربما لا تكون الاختلافات الرئيسية ناتجة عن عوامل بيولوجية أو مناخية مباشرة ولكنها مرتبطة جزئيًا بالأنماط المختلفة لارتفاع مستوى

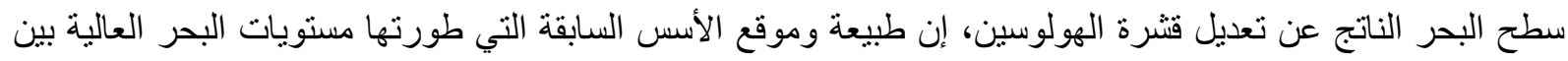
الجليدية وبين المناطق أمر بالغ الأهمبة بشكل خاص ويتم التحكم فيه إلى حد كبير من خلال العو امل التكوينية الإقليمية ، وخاصة الهجوط طويل الأجل. لشعاب المرجانية الصلبة هي مثال رئيسي للكائنات المستعمرة التي تملي مورفولوجي بشكل مبانشر استراتيجيات تاريخ الحياة (جاكسون 1979) ، والمعدلات الديموغر افية (مادين وآخرون. 2014 ؛ ألفاريز-نورييجا وآخرون. 2016 ؛

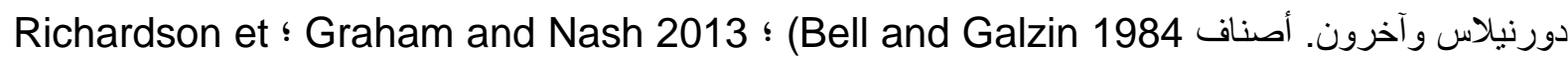
al. 2017b). معظم الكتلة الحيوية الحية مرتبطة بالسطح. هذه الخصائص لها عو اقب على العمليات الحيوية مثل النمو و البقاء على قيد الحياة ، حيث تسمح نسب مساحة السطح إلى بلى الحجم الأعلى بالمزيد من الكتلة الحيوية لكل وحدة استثمار في الهيكل العظمي ، ولكنها قد تزيد من خطر موت المستعمرة

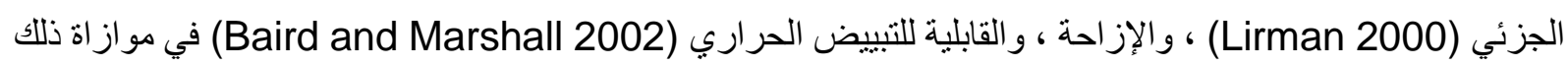
، توفر الهياكل المرجانية موطنًا مباشرًا للعديد من الأصناف ويمكن أن تعمل كملاذ مفترس لكل من الأسماك البالغة والصغيرة على نطاق السو ائل ، يساهم التباين في مورفولوجيا كل مستعمرة في التجمع في التعقيد الهيكلي العام للموئل

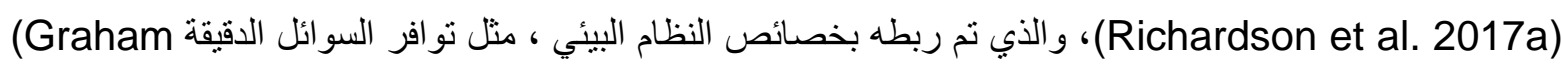

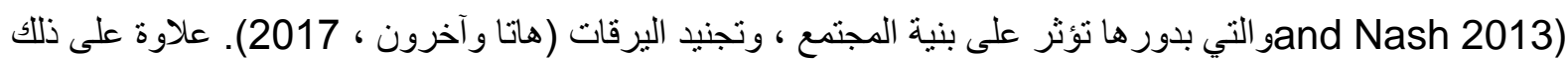

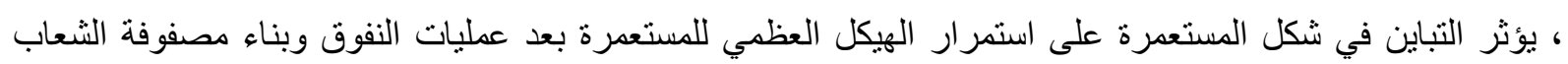
المرجانية وعمليات الردم ومع ذلك ، على الرغم من أهمية علم التشكل لعمل كل من الثعاب المرجانية نفسها والنظم البيئية للشعاب المرجانية ، فإن الدراسات الكمية حول مورفولوجيا المرجان قليلة ، ويفترض أن ذلك يرجع إلى الصعوبات في لرئ

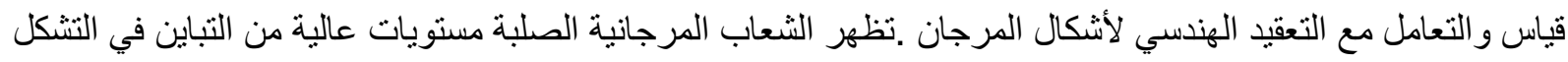
داخل وفيما بين الأصناف. و هي تختلف من الأشكال البسيطة ، مثل المستعمرات المغطاة أو نصف الكروية ، إلى الأشكال

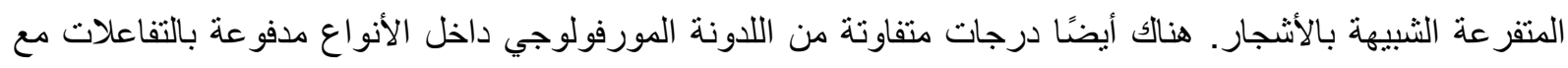
الظروف البيئية المحلية ، على الرغم من أن بعض الاختلافات بين الأنواع مقيدة وراثيًا ،تضيف الظواهر الإضافية مثل دأل الوفيات الجزئية ، وتفتت المستعمرة و النمو غير المحدد إلى التعقيد و التباين الملحوظ في التشكل من مستعمرة إلى مستعمرة التهرة

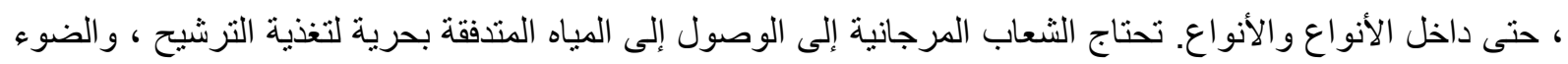




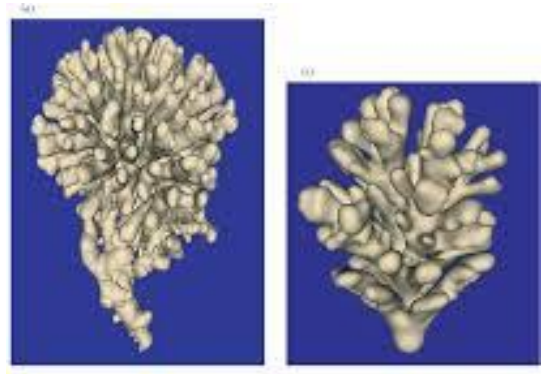
من أجل التمثيل الضوئي ، وكلاهما مرتبط بالتنوع المورفولوجي، بالإضافة إلى ذلك ، تؤدي المنافسة على الفضاء إلى نشوء العديد من

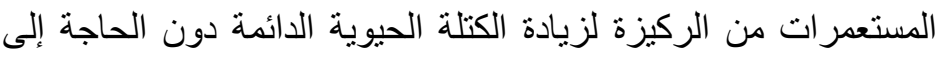

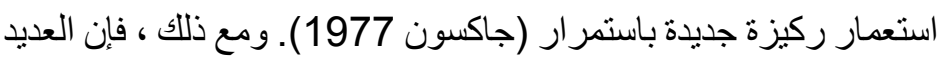

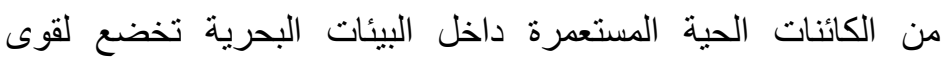
هيدروديناميكية يمكنها إزاحة مستعمرات بأكملها إذا نمت بعيدًا جدًا عن لهن

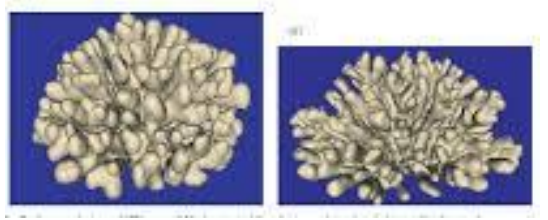

شكل رقم (10) نموذج يوضح لبنية المورفوجينيك في الثعب المرجانية

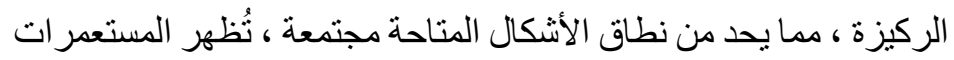

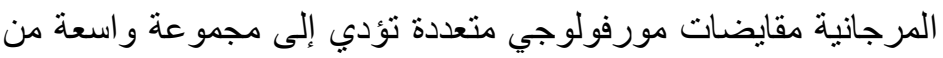
التباين الملحوظ في التشكل. يظهر في المرجان البحري التر اكيب المنتظمة و التي يمكن رؤيتها بالعين المجردة المجموعات المرجانية، حيث يتضح التشابه الناشئ من تكرار العناصر الأنبو بية و التي تجتمع في كتلة محكمة ولكن هذه الأنابيب بالإضافة إلي كونها مفردة ، وترتيبها أقل نظاماً ، إلا انه يوجد اثر واضح للبناء في الصفوف المنتظمة بها ، ويلاحظ علي المرجان البحري توافر قدر كبير من التوازن و الانتظام و التآلف القائم علي تكر ار الوحدة المفردة إلا أن هذه التنظيمات المورفوجينيك تتخذ شكلا هندسياً تماماً.كما في الثكل(10).

\section{• خامساً: علاقة الثكل بالحركة والتغيرات الناتجة عن فن المورفوجينيك :}

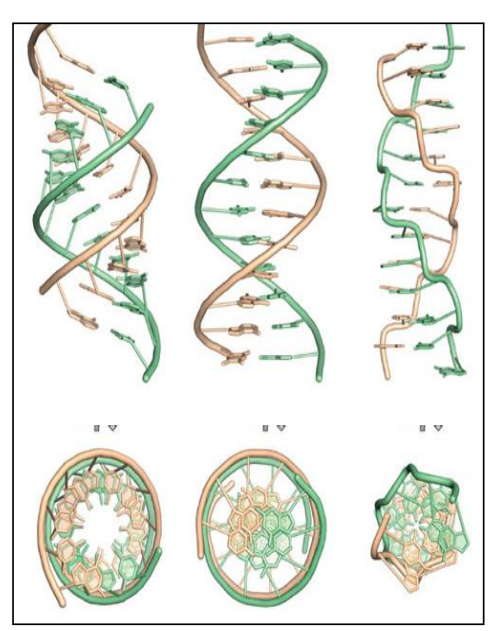

شكل (11) يوضح الثريط اللولبي في شكل حركة (DNA)

الثكل أحد العناصر الأساسية في التصميم و العنصر الشكلي بمكن تعريفة انه نظام متكامل يتخذ هويته نتيجة لفاعلية العلاقة التبادلية بين العناصر المكونة له ، ويقصد بتغير الوضع تغيير اتجاه محاور الثكل بالنسبة لاتجاهين الرأس و الأفقي أو

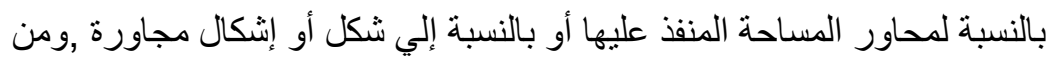

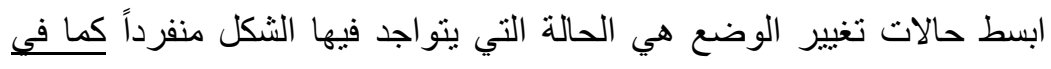

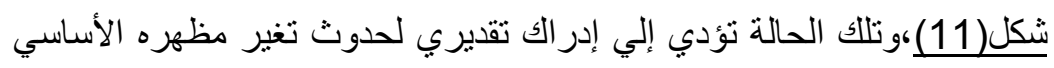

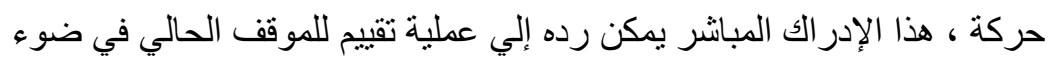

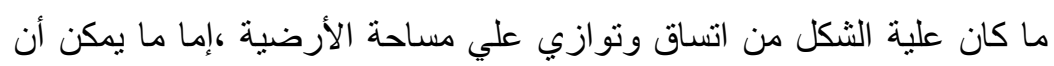
تؤول إليه حركته ، وهذا التقنين يحدث في إطار عوامل متعددة ،وتتداخل فيه الخبرات السابقة بالأشياء المتحركة ، وفي الرغبة لرؤية الثنكل منو ازناً ومنسقاً علي الأرضية. - مات.

وتغيير الوضع بهذه الطريقة يؤدي إلي تغيير داخلي لحركة الثريط الور اثي وقدرته علي إنارة الانتباه من خلال تغيير زواياه فهي حركة تثير الانتباه بدرجة أكبر من الوضع المستقر ، ويؤدي ذلك أيضاً إلي تغيير فاعلية الفراغ المحيط بالثكل نتيجة لما يؤدي إلية هذا الوضع من إضفاء التنوع ويحول الطابع السكون إلي طابع اكثر ديناميكية.

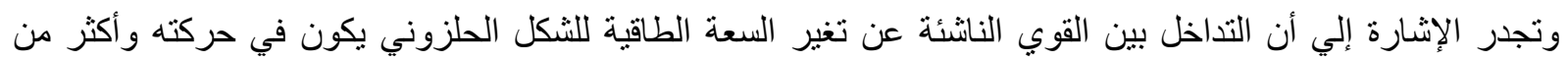


أـ التصميم المورفوجينيك في الفراغ:

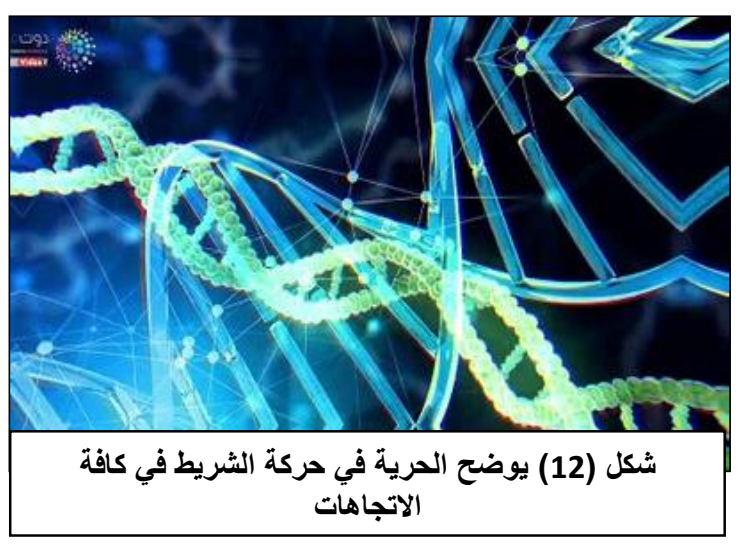

وقد يثار الجدل حول مدي نوافر النظام البنائي في التراكيب

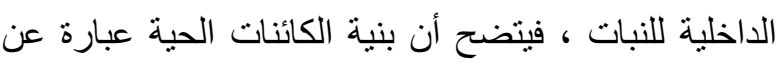

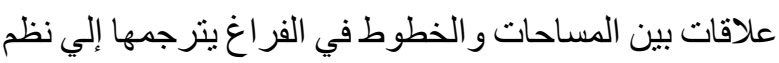
بنائية متحركة في الفراغ ، فهذا النظام داخل قوانين تتمو بمقتضاها العناصر الطبيعية حيث تعني السيطرة علي نظم ونسق العناصر الطبيعية ، ومن الطبيعي أن النظم الرياضية

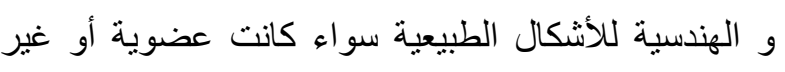
عضوية تتحكم فيها العديد من العو امل التركيبية مثل التنوع و التماتلل و الانتظام و التتاسب وذللك من خلال شبكات مرنة متحركة في الفراغ ، يوضح فيها المر احل الأولي لتحريك السطح

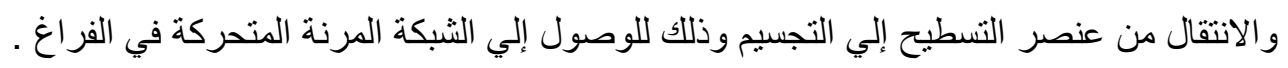

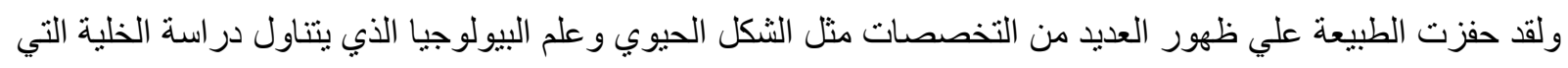
تتضمن النواه و البروتوبلازم و الجينات الور اثية (الجينوم) أو ما يطلق الدنا DNA ويدفع هذا إلي الاهتمام بدر اسة التركيبة

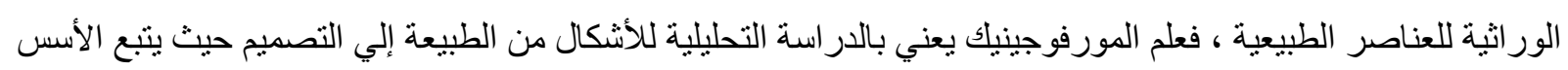

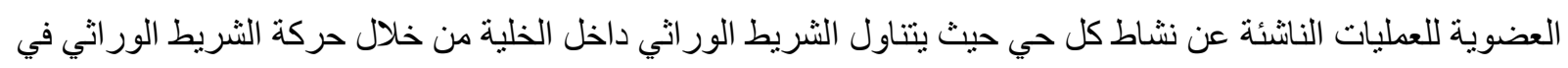
الفراغ.

يوضح الثريط الور اني داخل الخلية (الجينوم) يوضح محاكاة متقدمة في إعادة صياغة للشريط الور اثي بشكل تصميمي يوضح الحركة في الفراغ مع عنصر التكرار و التكبير و التصغير مع الالتفاف .ويوضح حركة الاهتزاز و المرونة في الحركة للشريط بشكل حر كما في شكل رقم(12) ـ فعلم المورفوجينيك يعني بدر اسة حركة الأشكال الجينية داخل الفراغ في الخلية والذي يتناول المظهر البنائي الجيني الداخلي والتركيبي لعناصر الطبيعة .

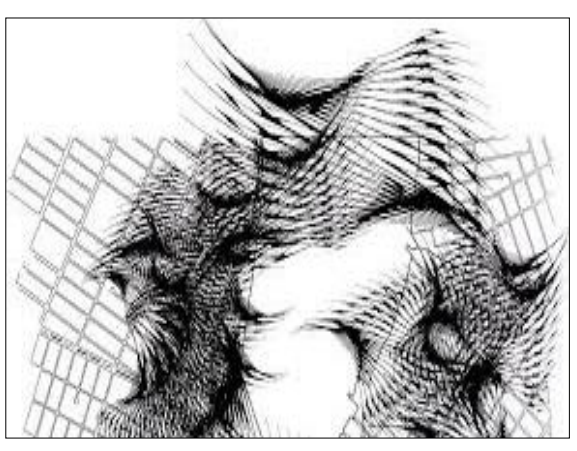

شكل (13) تصميم قائم علي الثبكة المرنة المتحركة في الفراغ ذو الإبعاد المتعددة

\section{بـ التصميم المورفوجينيك والإبعاد المتعددة :} ينشأ عن انتظام مفردات الطبيعة داخل بنية هندسية نظام بنائي هندسي يتشكل من عناصر و هيئات وأنواع متعددة من التقسيمات داخل النظام و إنتاج مستويات من الأنماط الهندسية المسطحة أو المجسمة تثنير إلي منئ نظم جديدة. فالنظام المورفوجينيك قائم علي شبكات مرنه متحركة في الفراغ تعطي

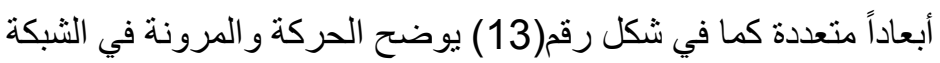
المتعددة الأبعاد.

ولقد انبثق علي هذه العمليات الحيوية دراسة للنظم البنائية في الطبيعة

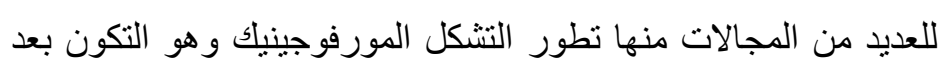
عملية التشكيل وهو ناتج عن العمليات الحيوية العضوية والذي ينشأ من نشاط أعضاء الكائن الحي كلها بوصفها نطام عضوي منكامل" فهنسة الطبيعة قد مهدت التفكير إلي إيجاد طرق جديدة لحل شفرات معظم الظواهر الطبيعة المعقدة للوصول إلي نهاية بسيطة من خلال صور من الأنماط الهندية المتكررة ذات الأصول البسيطة و المستمرة و المتضاعفة . 
فالنظام البنائي في الخلية قائم علي وحدات مركبة وهذه عملية متوفرة في الأغثية البيولوجية وهذه المركبات مكونة غاليا

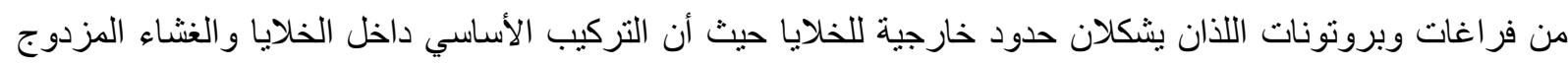

والطبقات المفر غة غشاء مكون من فر اغات وظيفية مزدوجة فار غة وهي أساس لكل الأغثية البيولوجية. إن مفهوم DNA الدانا يتحكم في شكل المخلوقات من خلال آلية معقدة للأختلافات الخلوية حيث أن من خلال منهجية النظام

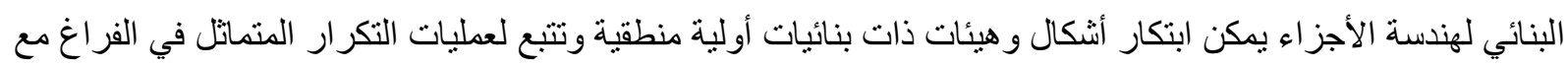
التضاعف العددي المستمر تتبع كيانات أكثر تعقيدا لتضيغ في الفراغ مع التضاعف العددي المستمر تتبع كيانات أكثر تعقيد لتضيغ عملاً متكاملاً حيث ينتج نظم متعددة الأشكال Polymorphism مستوحاة من التصميم المورفوجيني ويرتبط

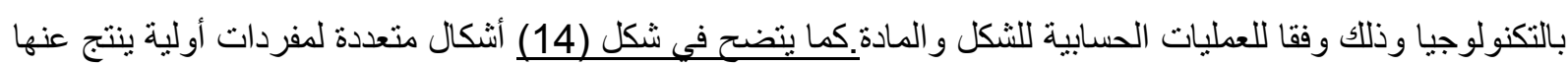
مجمو عات تصميمات مختلفة من إنتاج الباحثة.
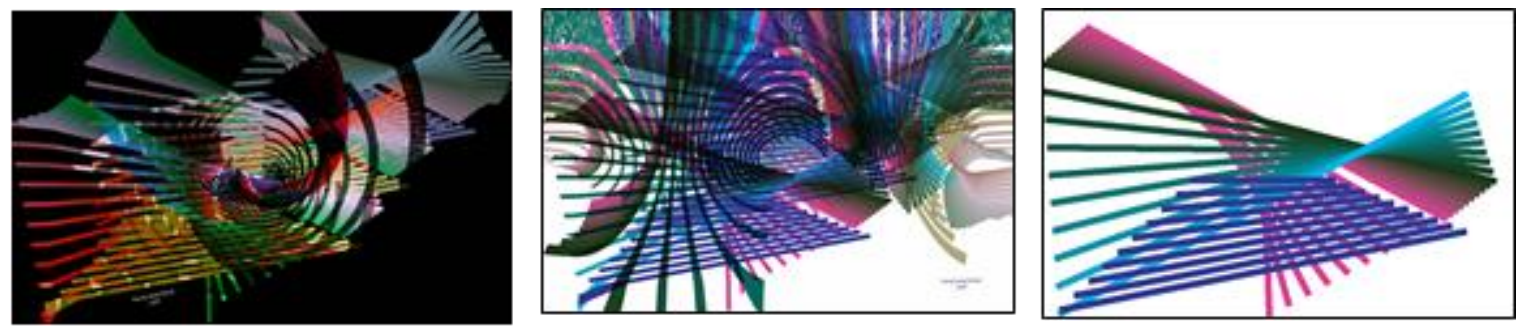

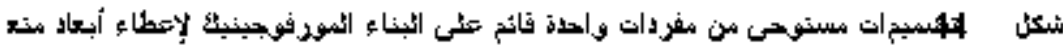

\section{• ساداً: الصيغ البنائية للتصميم المورفوجينيك في مجال الكمبيوتر:}

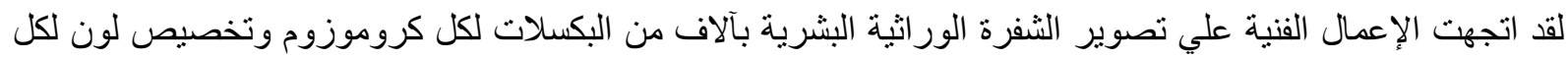
قاعدة من قو اعد الأربعة T,C,G,A و هذا مزيج بين العلم والفن بين أنماط متنوعة وغريبة من الصور يمكن مشاهدتها

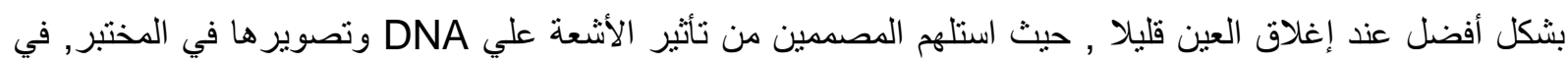

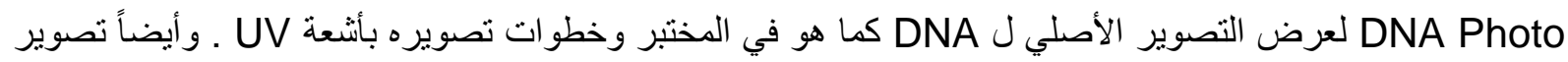
لثكل DNA الرقمية الفريدة في علم الور اثثة ، وأخذ عينة من DNA مسحة الفم يعطي طابع شخصي فريد للصورة. و أيضا يصور الجمال " سونو TL Soto " بالكمبيوتر وجمع العلم والفن وهي صورة نسميها صور الجيني الوراثي وهي لرهي عبارة عن صور رقمية من جينات DNA العقلية التي عولجت بتصاميم تأثيرية وكل صورة تعبر عن الطبيعة العجيبة للخلق ، كما تظهر كتل البناء الأساسية من الخلايا وهي صورة فريدة يمكن للمصمم أن يستوحي من خلالها تصميمات معالجة بير امج الكمبيوتر وهو ما يسمي بالفن الحيوي Bio Art وهو ممارسة الفن و إنتاج أعمال فنية داخل المختبر أو استوديو هات

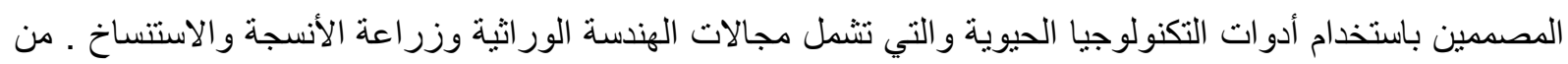
خلال خلايا الحمض النووي DNA و البروتينات و الأنسجة الحية وتخليق الكائنات الحية وتطبيقها في علوم الحياة الأخلاقية و الاجتماعية و الجمالية.

ويساعد الكمبيوتر المصمح علي تتمية قدر اته الحركية والإبداعية سواء أكان ذلك الفنان المبندأ أو المتمرس ،ويعد استخدام الكمبيوتر وسيلة طيعة لمساعدة المصمم للوصول إلي حلول تشكيلية غير تقلبدية من خلال إمكانات برامجه المتعددة التي تحقق الحركة الفعلية والإيهامية في مجال التصميمات الزخرفية ، ويتيح الكمبيوتر توظيف تعدد الاحتمالات للعمل الفني الو احد مما يساعد المصمم علي حرية الانطلاق نحو التعبيرات الحركية . 
إن الإمكانات الأدائية لجهاز الكمبيوتر في إظهار الحركة تتسم بسهولة محو الأخطاء أو تعديل الحركة والأشكال المؤدية

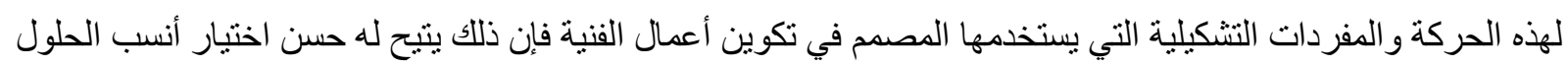
التشكيلية التي تتفق مع طبيعة الموضوع التشكيلي المراد التعبير عنه .

تتيح بر امج الكمبيوتر للمصمم في تحقيق الحركات بجميع أنو اعها واستخدام وسائط وادو ات تنفيذية مختلفة سواء كانت تقليدية أو غير تقليدية بشكل ميسر وبسر عة تفوق كثيرا استخدام تلك الوسائط والأدوات بالثكل التقليدي المألوف. ومن هذا المنطلق تتيح برامج الكمبيوتر للمصمم إمكانيات لانهائية للتجريب في التصميمات الزخرفية من خلال التهات استخدام

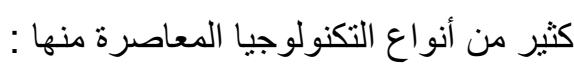

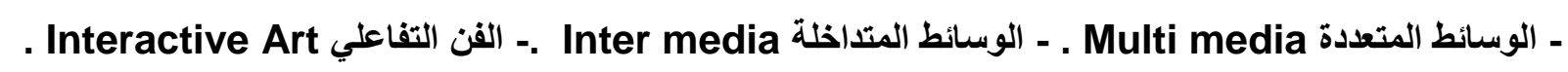
ـ الواقع الافتراضي Virtual Reality ـ ـ فن الفيديو . Dideo Art ـ ـ الفنون الرقمية Digital Art .

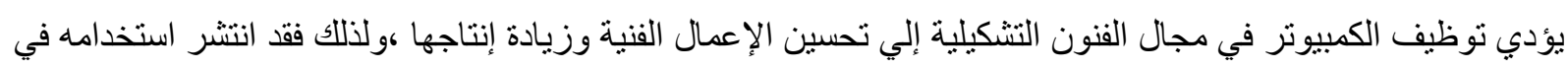

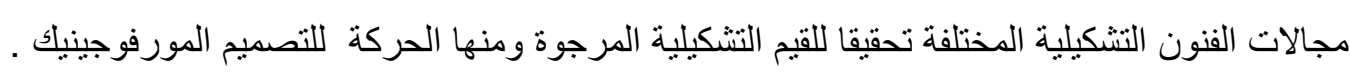
ويجذب الكمبيوتر باعتباره أداة عصرية جديدة انتباه المصمم التشكيلي بما يقدمه من مثير ات حركية متنو عة تسهم في سهولة إظهار الحركة الفعلية والإيهامية بما يحقق للفنان نوعا من المتعة التي تجيبه في الناتج الفني.

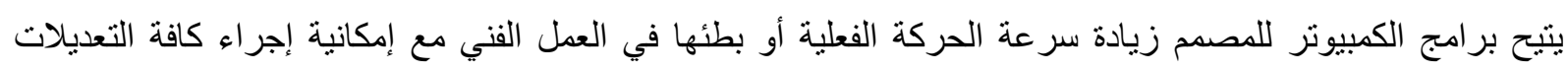
و الإضافات في البيانات والمعلومات بصورة سريعة لم يكن من السهل التوصل إليها بالطرق التقليدية ولم يكن في الإمكان أيضا تحقيقها في نفس المدة الزمنية . ويسهم بر امج الكمبيوتر في مجال الفنون التتكيلية إلي تنشيط قدرته الفنية الابتكارية الأمر الذي يؤكد أهمية ذلك في مجال الفنون الحركية مثل فن المورفوجينيك وفقاً النتكل الذاتي.

يساعد بر امج الكمبيوتر المصمم علي تتمية قدر اته الحركية والإبداعية سواء أكان ذلك المصمم المبندأ أو المتمرس.

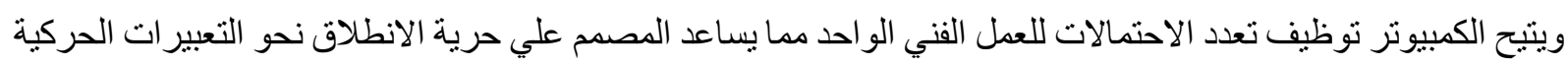
التي تتفق واستعداده وميوله الخاصة وبالتالي فإن ذلك بسهم أيضا في تأكيد الأساليب الفردية للفنانين.

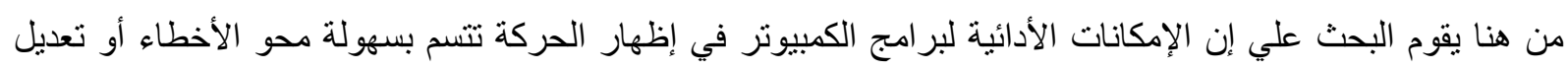
الحركة والأشكال المؤدية لهذه الحركة والمفردات التشكيلية التي يستخدمها المصمم في تكوين العمل الفني فإن ذلك يتيح للباحثة حسن اختيار أنسب الحلول التشكيلية التي تتفق مع التصميم المورفوجينيك. توفير برامج الفوتوشوب Adobe illustratorcs Photoshop ، للباحثة إمكانية تحقق الحركة بأنواعها المختلفة و استخدام وسائط و أدوات تتفيذية مختلفة سواء كانت تقليدية أو غير تقليدية بشكل ميسر وبسر عة تفوق كثير ا استخدام تللك

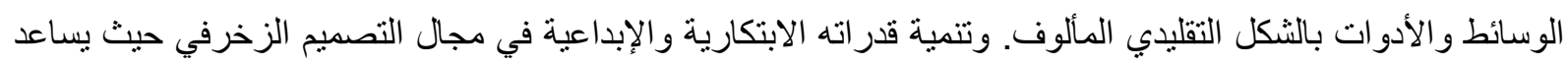
ذللك علي رفع كفاءته ومهارته . و البحث الحالي يهتم بالفنون الرقمية Digital art وهي فنون مخلقة بالكمبيوتر بصورة رقمية ويمكن أن تتنج تلك الفنون بالكامل داخل الكمبيوتر كما في حالة الفنون الجزيئية Fractal art و يمكن إدخال العديد من المدخلات داخل الكمبيونر بالئر كالصور الفوتوغر افية والرسوم الخطية Drawings ومن ثم تعديلها يشكل كبير حتي لايتبقي منها إلا مجرد أطياف من

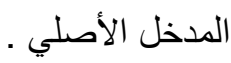
حيث لم تعد التقنيات الرقمية بشئ جديد علي عالم الفن ولم يعد الوسيط هو الرسالة في حد ذاته فأصبحت الأدوات الرقمية

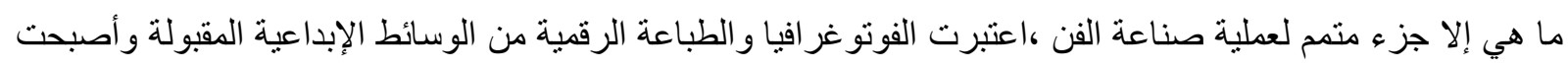


تعرض في المتاحف وقاعات العرض الكبيرة علي مستوي العالم و اكتسب فناني الفنون الرقمية مسرحا جديدا من خلال فنون الثبكة Net art و الفن المورفوجينيك وكذلك فنون بر امج العقل الالكتروني Software art ـ ويمكننا تصنيف الفنون الرقمية إلي عدة تصنيفات رئيسة:

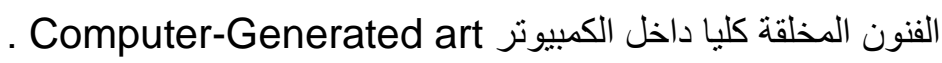
الفوتو غر افيا الرقمية Digital illustration هي أعمال فنية تتتج باستخدام محاور رياضية من خلال بر امج جر افيكية.

\section{سابعا: الفنانوا الأين استخدموا المورفوجينيك في مجال الكمبيوتر:}

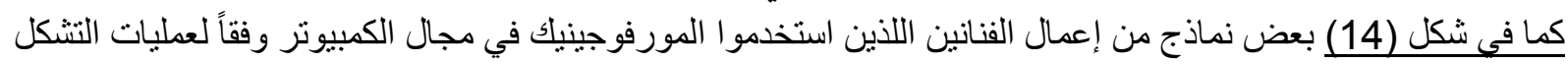
الذاتي أدم ماركوس Adam Marcus وقد اهتم بالتقنيات والوسائل التطبيقية في مجال التصميم بمساعدة الكمبيوتر

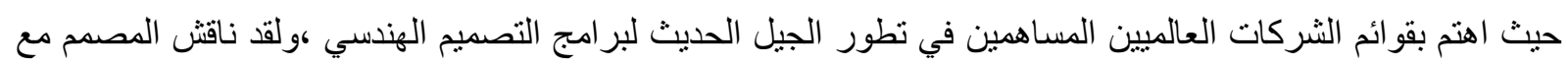
أعضاء جماعة الهندسة الذكية (روبرت ايش) رائد بحث في أنظمة (بينلي) ،و(لاس هيسليجرن) رائد أبحاث وتتمية بلندن ،

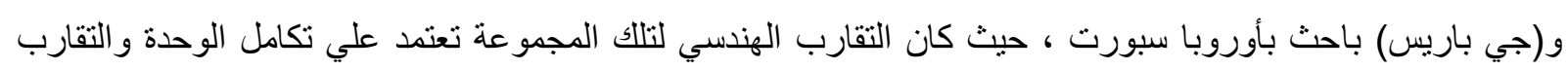
الهندسي لتلك المجمو عة يعتمد علي تكامل إبداعي من الممارسة لفن المعمار وتطور بر امج التصميح بالكمبيوتر. و الفنان كوني لي Connie Lee وهو ما أهم المصممين في قسم علوم الكمبيوتر في جامعة كالجاري في البريا بكندا ، ولقد أوضح الجانب التطبيقي واهتم بالتصوير الدقيق (الميكرو) لإظهار أدق التفاصيل الجمالية للأشياء حتي لأدق الكائنات

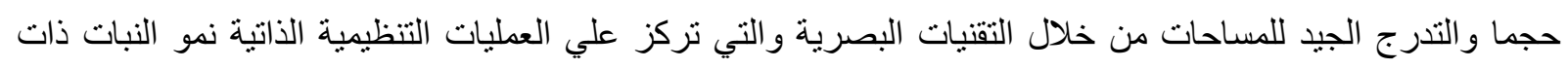
الصلة بالعمليات المرئية و التكنولوجية في مجال الكمبيوتر،حيث أجري المصدم العديد من الأعمال الفنبة المرتبطة بنظرية المورفوجينيك واستخدمها في تطوير طريقة التفكير الفني من خلال دراسة جزئياتها المختلفة التي تتبع نسقا بنائيا هندسيا

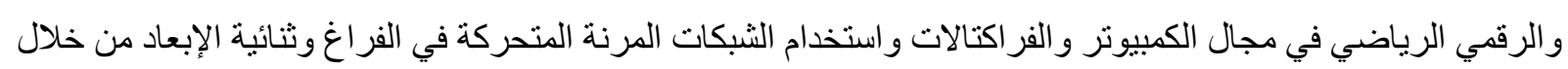
بر امج الكمبيوتر.

و الفنان ليود أرجون Lioyd Aragon و هو من أهم الفنانين المؤسسين لمشروع PAGE وهي أحد الشركات المؤسسة للخلايا الصناعية القابلة للبرمجة ،حيث أنه مكون من أربعة جامعات داخل مشروع أمريكي أوروبي ،وهو هو تابع للمؤسسات

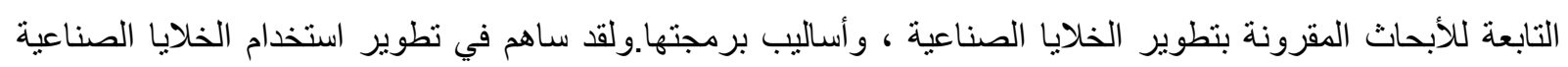
المبرمجة ، ولقد حقق المصمم حوارات علنية مقرونة بتكنولوجيا الإحياء، وبروتوكولات مقرها مسخرة لتطوير الكيمائي

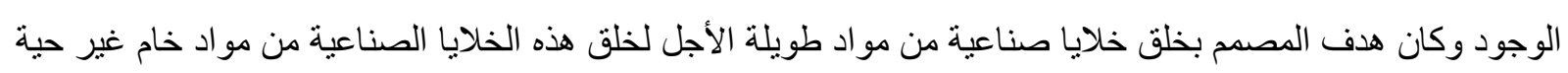
،وبرمجتها بالأداء الكيمائي المطلوب ، حيث وضع استر اتيجيات جديدة لتحضير ات فنية لعمل مو اد خام أساسية ، وتركيبات حديثة تعتمد علي النماذج الحيوية للعمليات بو اسطة إنتاج أنثكال صناعية من خلال النظام البيولوجي و النظام البنائي للتصميم المورفوجينيك.

و الفنان جيمس فينسنت James Vincent عالم البيولوجي المجري ، نوصل إلي نماذج النمو الخاصة بالكائنات البسيطة المتعددة الخلايا ، وبدأ يطور وصف رسمي لتطور نمو الكائنات البسيطة وسمي هذا النظام (ليزر ماسبير) وهو ما يسمي توني في الكمبيوتر بالقو اعد الرسمية ،و هو نركيب يصف لغة رسمية من خلال تتابع الأشياء البسيطة ، ولقد اهتم بعلم البيولوجيا الذي ارتبط بنمو وتطور الكائنات من خلال التنظيم الور اثي لنمو الخلية ، وتثكلها من خلال نمو الخلية وحجمها و وأشكال

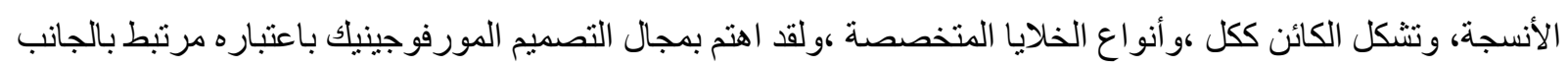

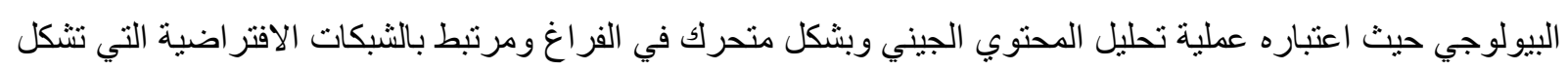


من خلالها الكائنات الحية وربط المصمم بين التصميم المورفوجينيك ودر اسة للجو هر الداخلي للعناصر العضوية لاستخلاص نظمها الهندسية المجسمة ثنائي وثلاثية الإبعاد و إيحاء بالتجسيخ.
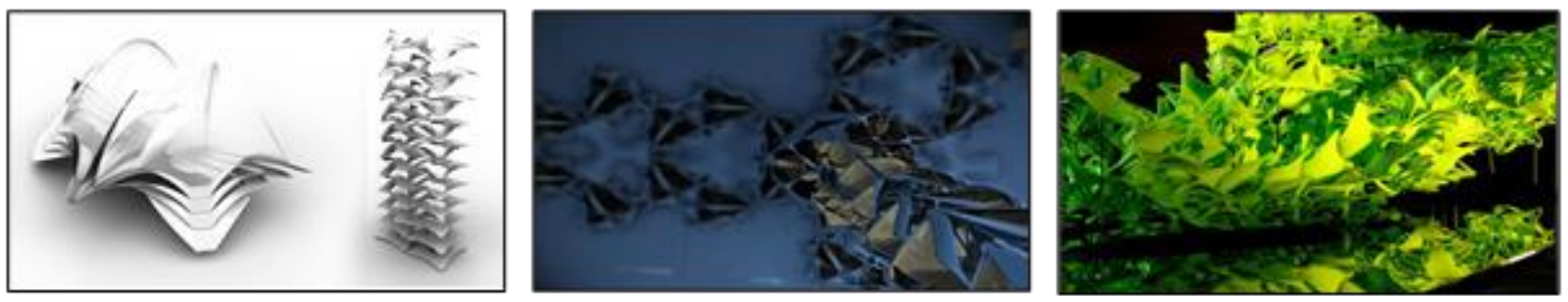

شكل (14) مجموعة من التصميمات باستخدام الكمبيوتر مستوحى من النظام الثبانى للتصميم المورفوجينيك

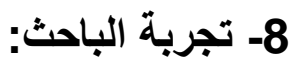

تهنم الباحثة إلي استحداث تصميمات للوحة الزخرفية مبنية علي الأصول البيولوجية داخل الوراثية المتمثل في الثريط الور اثي التي اعتمدت عليها النظم البنائية للتصميم المورفوجينيك وذلك من خلال مرونة الحركة و إيجاد صياغات ابتكاريه

جديدة باستخدام الكمبيوتر جر افيكي من خلال تحديث الفكر الخاص بقسم التصميمات الزخرفية.

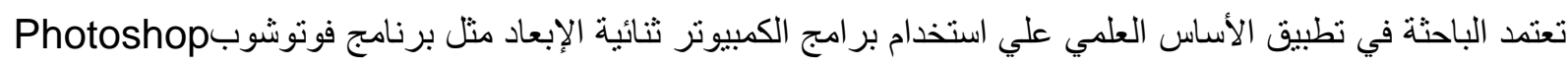

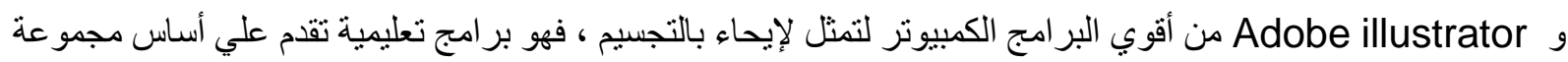
من التقنيات الحديثة التي تسمح بإجر اء العمليات المغيرة للسطح و التي توضح الحركة في الإيحاء بالتجسيم.

\section{تعتمد فكرة البحث علي عدة محاور كما يلي:-}

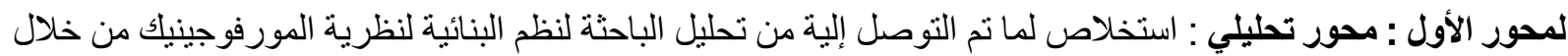
المتغيرات لخلايا للشعب المرجانية والظاهر الطبيعية بلور ات التلج لنظهر مستويات التفاعل التشكيلي في العلاقات الزخرفية بين عناصر التصميم ( النقطة ، الخط ، المساحة ، الملمس ، الثكل و الأرضية ، اللون ، الحجم و الظل و النور و إيحاء التجسيم و التحوير) المحققة من خلال تطبيق بعض إمكانيات برامج الكمبيوتر ثنائية الإبعاد و إيحاء بالتجسيم من خلال برنامج

فونوشوب و و Photoshope illustrator التأكيد علي منو الية الأشكال الثعب المرجانية وبلورات التلج وذللك لابتكار تصميمات تقدم تصور ات مختلفة ومبتكرة لصياغة الثبكات و المفردات المسطحة والإيحاء بالتجسيم لإنتاج علاقات شكلية تضفي نوعاً جديداً من القيم الجمالية والعلاقات التكوينية للتصميمات الزخرفية من خلال المداخل التجريبية. أما برنامج فوتوشوبPhotoshop وهو بتقنيات حديثة من تكرار وشفافية وتحوير وحركة بالإيحاء بالتجسيم مع التقطيع إلي أجز اء و إيضاح العمق مع الحركة و التكبير و التصغير وتحويل الإشكال وتغيير بنيتها الأساسية ، ولقد استفاد من المصمم.

المحور الثاني: محور تجريبي وبناء التصميمات المورفوجينيك. يحتوى هذا المحور علي تنفيذ عدة تجارب باستخدام البرمجيات ثنائية الإبعاد ( إيهامي / حقيقي) لانتقاء نماذج تصميمية يتم تطبيقها عملياً نوضح مفهوم التصميم المورفو جينيك وتوظيفها في تصميمات رقية ثنائية الإبعاد من خلال المتغير ات لخلايا للشعب المرجانية والظاهر الطبيعية بلورات الثلج .

$$
\text { المحور الثالث: التطبيقي للاراسة. }
$$

يشتمل هذا المحور على تنفيذ التجربة الملونة بو اسطة برنامج الكمبيوتر ثنائية الإبعاد وبرنامج فونوشوب Photoshopو

.Adobe illustrator 
في جدول يين من حيث نوع العناصر التصميمية والعمليات والأسس التصميمية المستخدمة عن النظم البنائية لتصميم المورفوجينيك.

\begin{tabular}{|c|c|c|c|c|c|}
\hline نطريه المورفوجينيك & القيمة الجمالية & عناصر التصميمية & الأسس التصميمية & عمليات التصميم & المفردة \\
\hline في حالة الثكل الجيني & و الإيقاع و الوحدة & 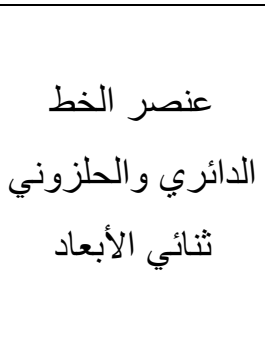 & عمق فر التكرار مناشي & و التكرار و التر اكب & المرجانية \\
\hline 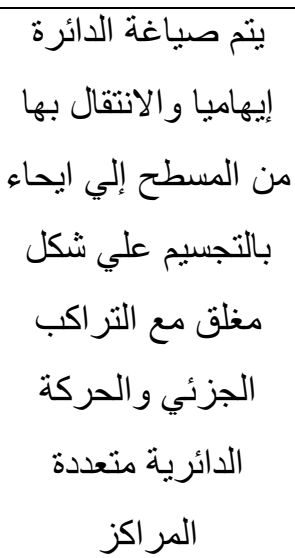 & بين أجز اء العدل والترابط & 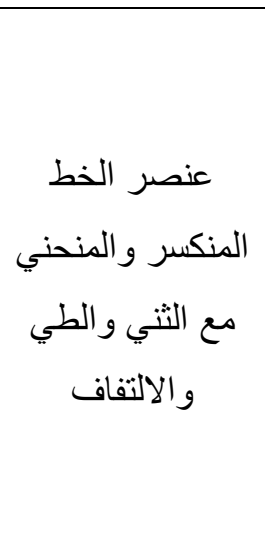 & نظ & الالكلي و الجزئي & بلورات \\
\hline
\end{tabular}

نماذج من البنية التصميم الناتجة عن البنية الافتراضية في نظرية المورفوجينيك للمتغيرات لخلايا للشعب المرجانية : (تكون من أربع مجموعات أ-ب-ج-د ) (18) )

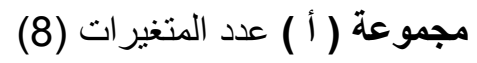

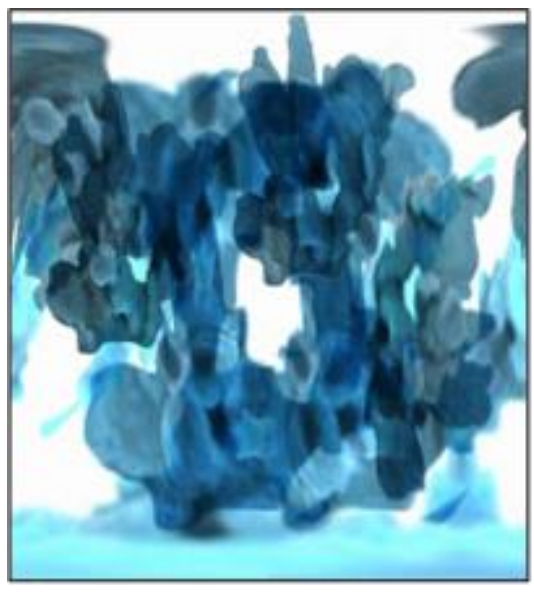

البنية التصميمبة الثاتجة عن عطليات التو اللا

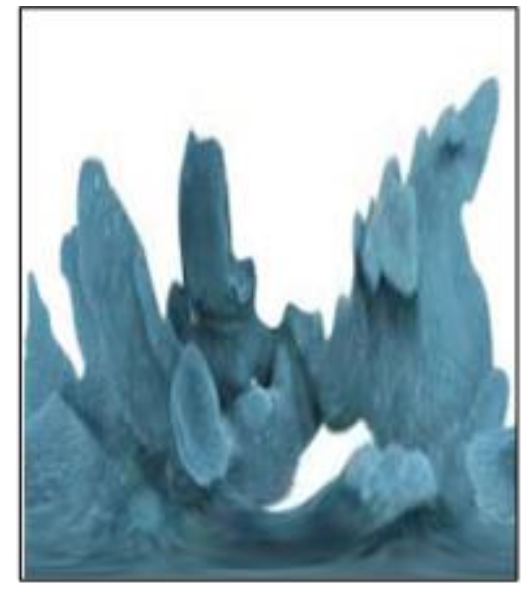

الثينية النصصيمية الناتجة عن عمليات الحركة

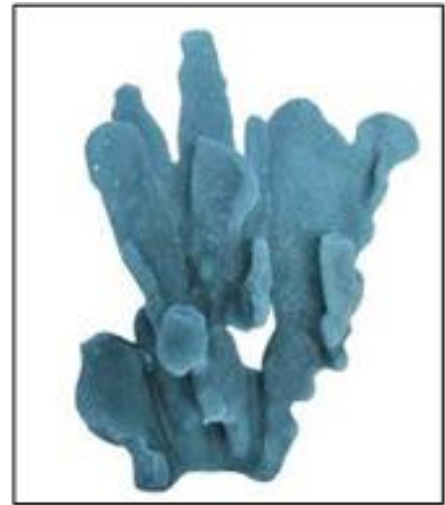

الثشكل الأسلسي الناتج عن البنّية الافترا اضيّة لمتَّيرات الخلايا للشعت المر حاتئة 


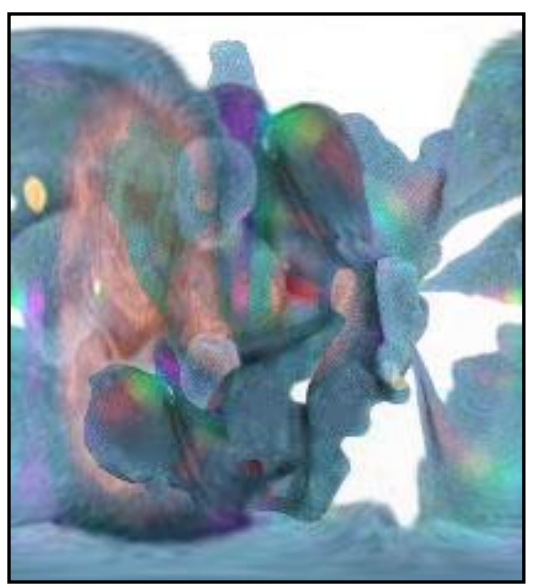

البنية التصميمية الناتجة عن

عمليات التراكب

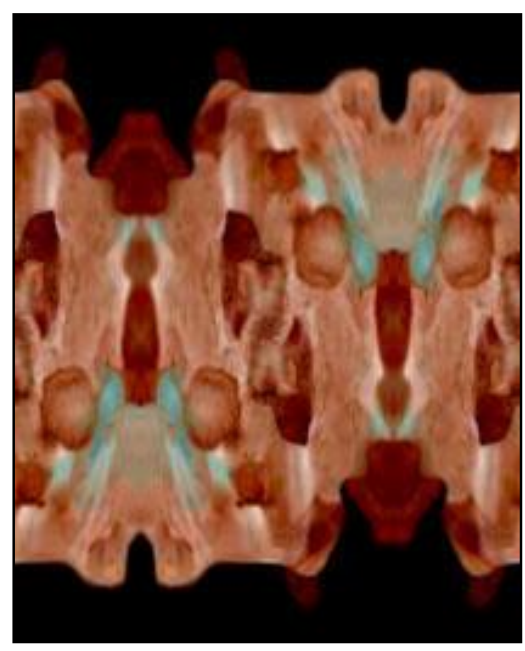

البنية التصميمية الناتجة عن عمليات الحركة

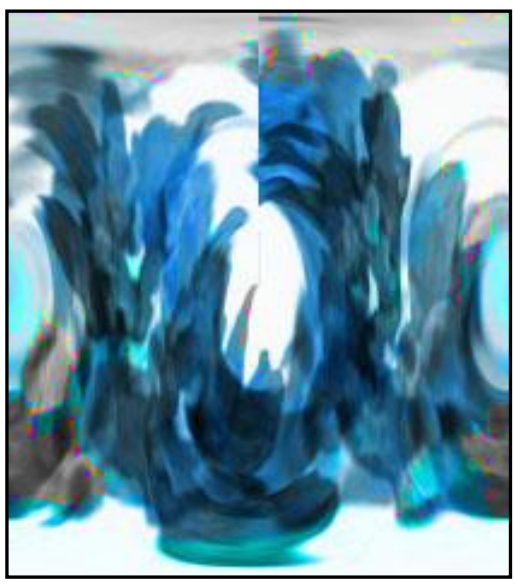

البنية التصميمية الناتجة عن عمليات التموج

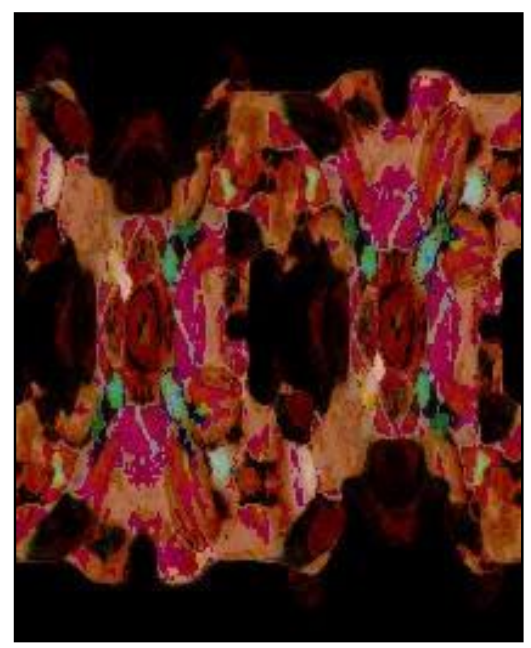

البنية التصميمية الناتجة عن عمليات التموج

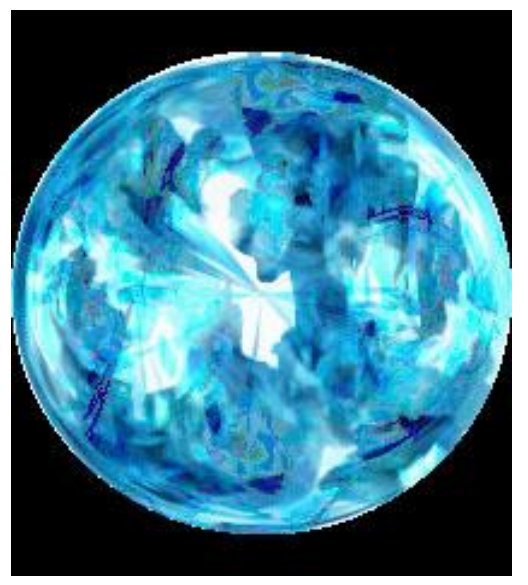

البنية التصميمية الناتجة عن عمليات الامجج

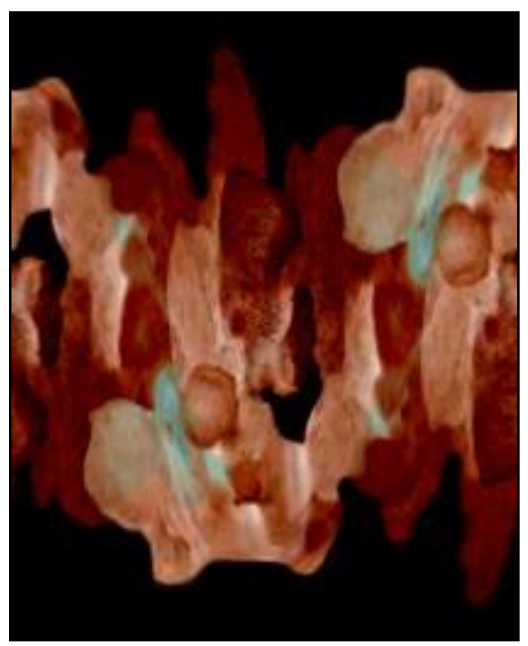

البنية التصميمية الناتجة عن عمليات التوالد التاتجة

مجموعة ( ب ) عدد المتغير ات (3)

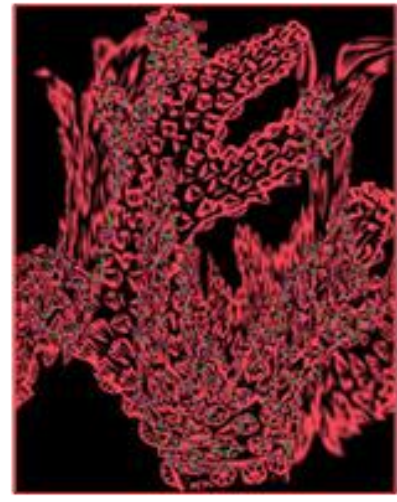

البئية التصميمية التاتجة عن

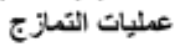

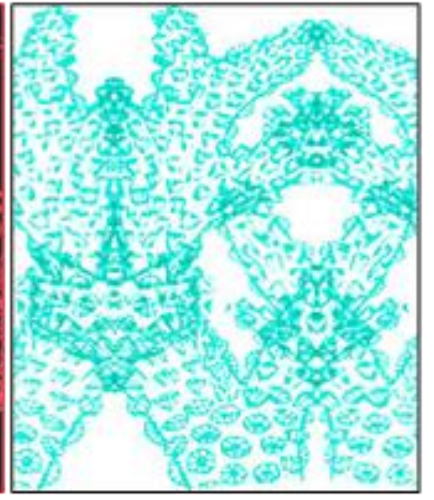

البنية التصميمية الناتجة عن عليات الثزراكب

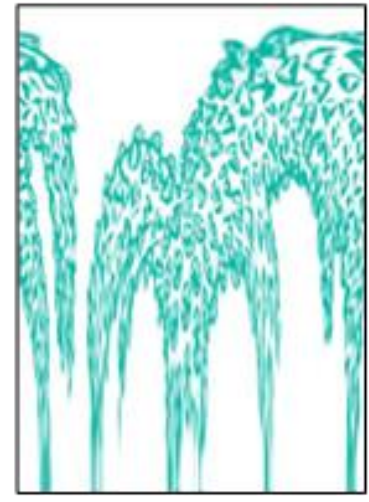

الينية التصميمية الناتجة عن عمليات التكراز

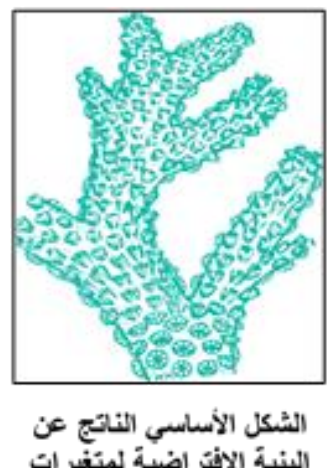

البنية الانتر اضبية لمتنغيرات النيات

الخلايا للمُعب المرجائية

مجموعة (ب) المبانيا 


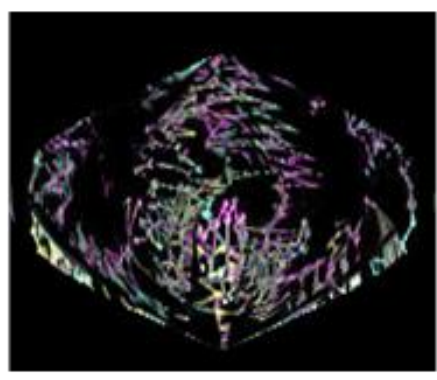

الثبنية التصميمية الناتجة عن عليات الحركة

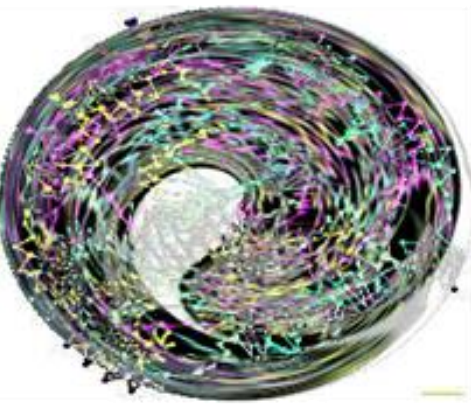

البنبة التصميمية الناتجة عن عمليات الثراكب

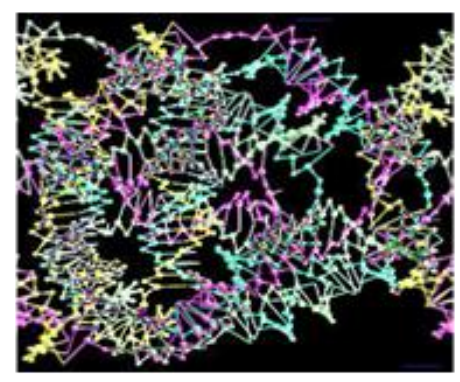

البنبة التصمبمبة الناتجة عن عليات التكرار

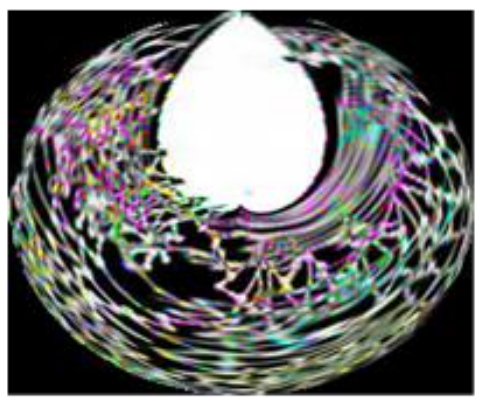

البنبة لتصميمبة الناتجة عن عمليات التماذج
مجموعة ( ج ) عدد المتغيرات (5)

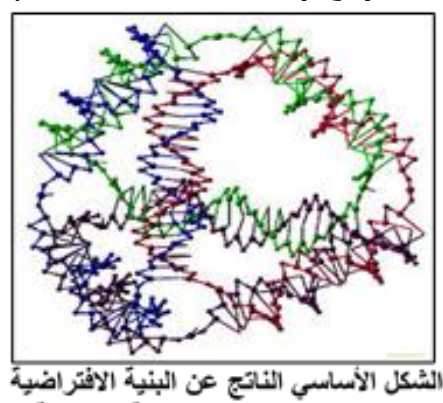

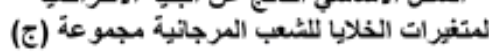

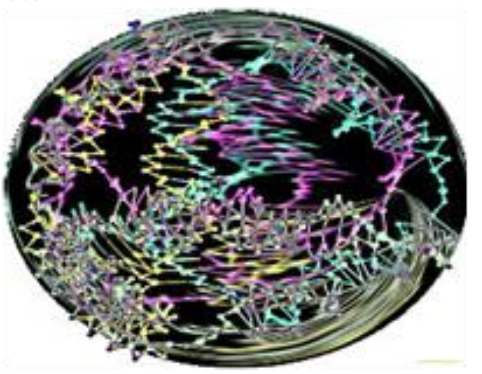

الينية التصصيمبة الناتجة عن عمليات التو الثا

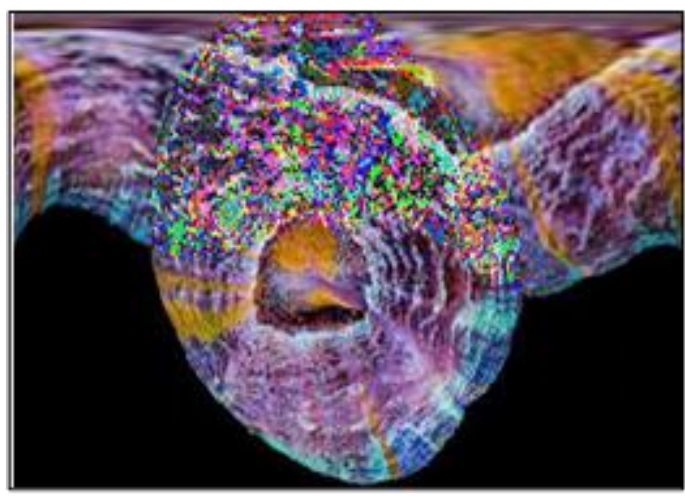

البنبة التصميمية الناتجة عن عمليات الحركة

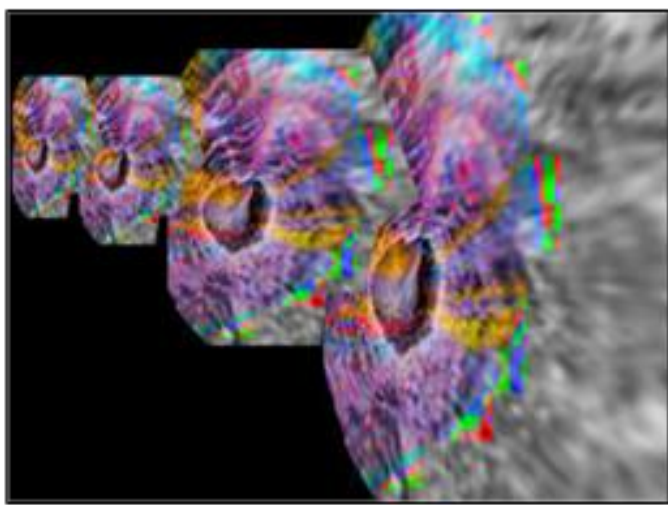

البنية التصميمية الناتجة عن عمليات التكرار
مجموعة (د ) عد المتغيرات (3)

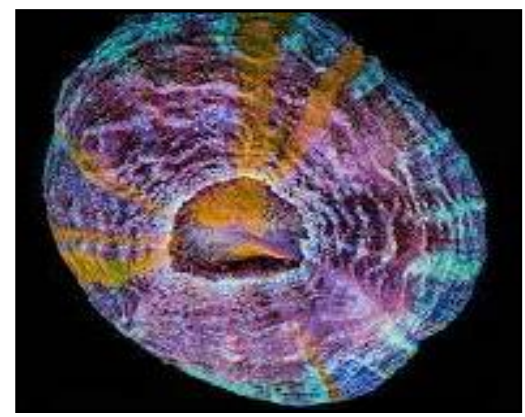

الشثل الأساسي الناتج عن الثبنية الاتئراضية

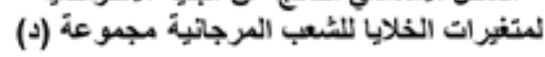

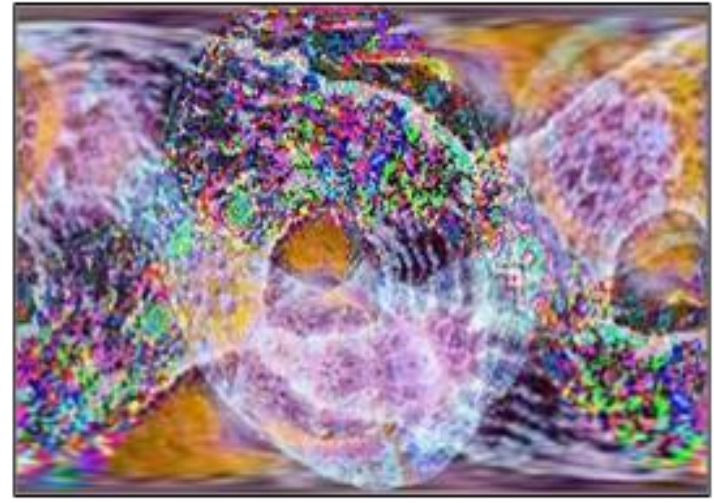

الينية التصميمية التاتجة عن عمليات التراكب 
نماذج من البنية التصميم الناتجة عن البنية الافتراضية في نظرية المورفوجينيك للمتفيرات بلورات الثنج :

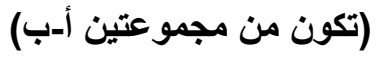

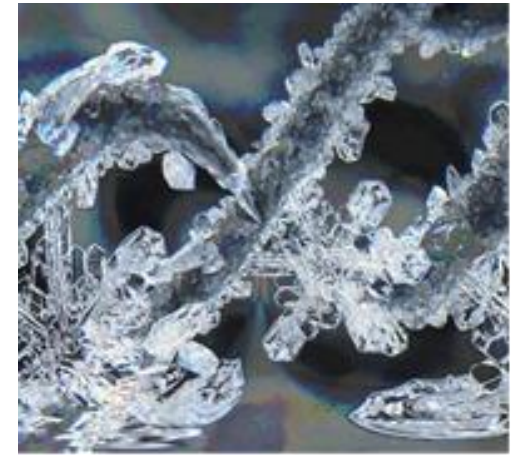

البنية التصميمية الناتجة عن التوالد

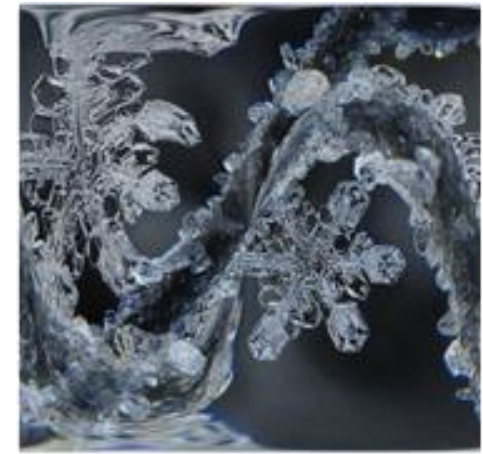

الثنية التصميمية الناتجة عن الحركة

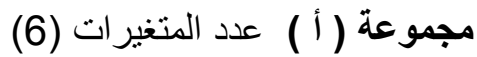

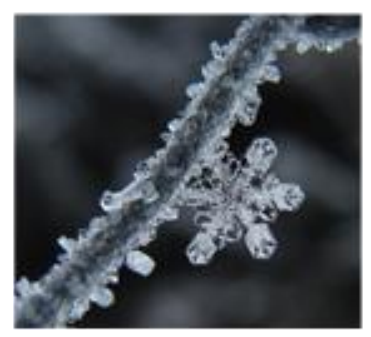

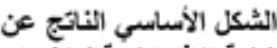

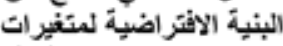

(i) بلورات الثلتج مجمواتئة
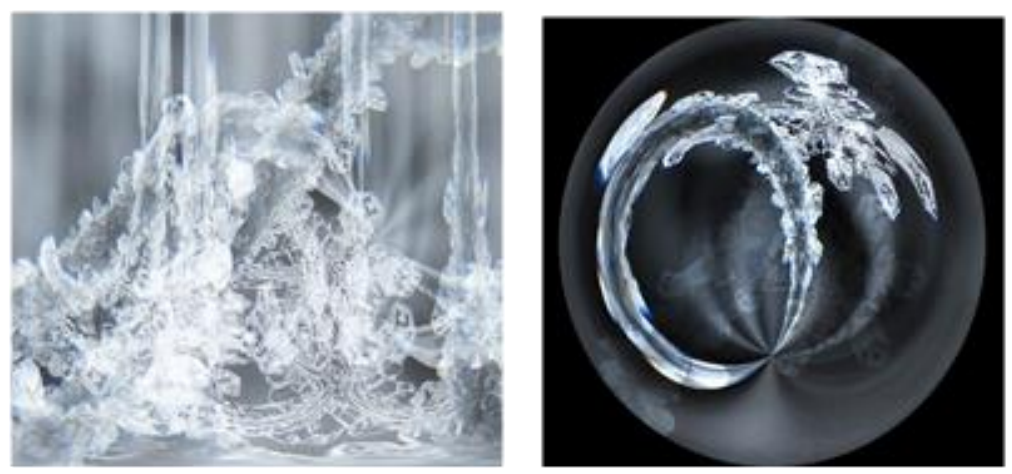

البئية التصميمية الثاتجة عن التموج والتمازج
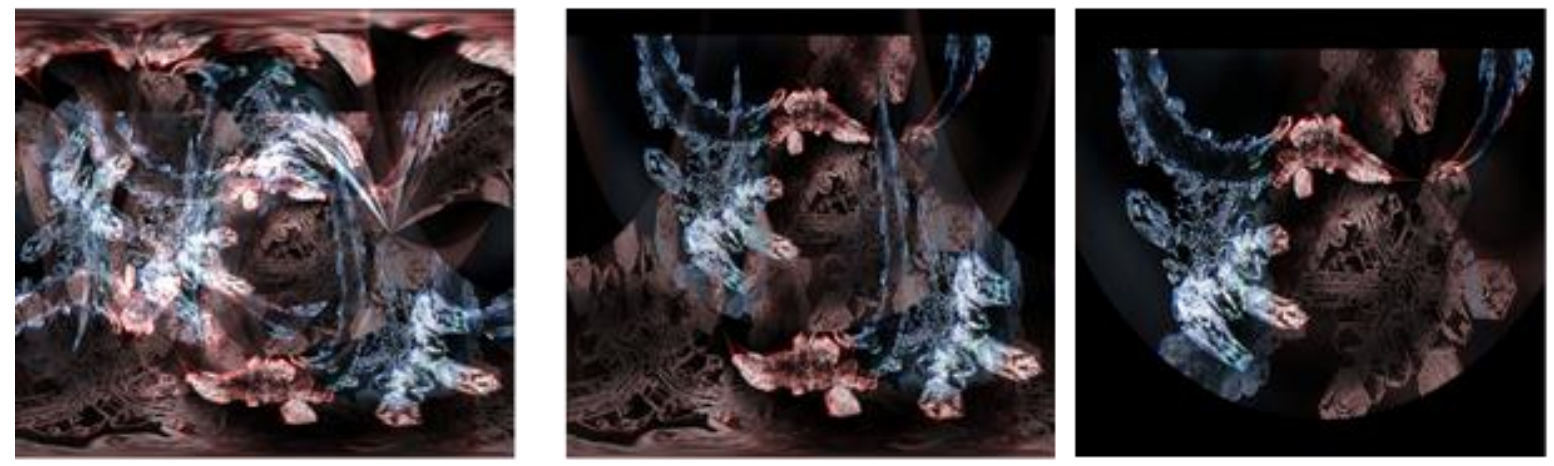

البنبة التصميمية الناتجة عن الحركة والتكراز و التوّ الد و التئراكب 
مجموعة (بـ) عدد المتغيرات (9)

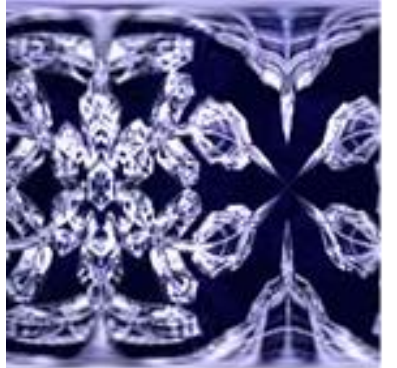

البنية التصميمِية النتاتجة عن الحركة والنكراز والتو الث والتراكب والتموج

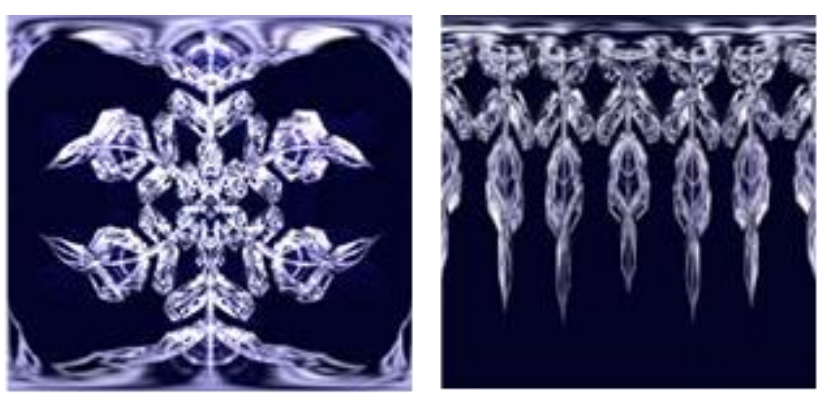

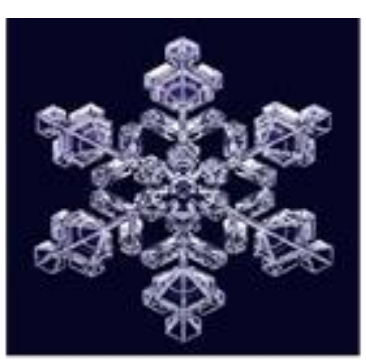

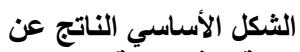

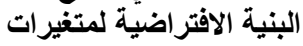

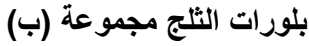
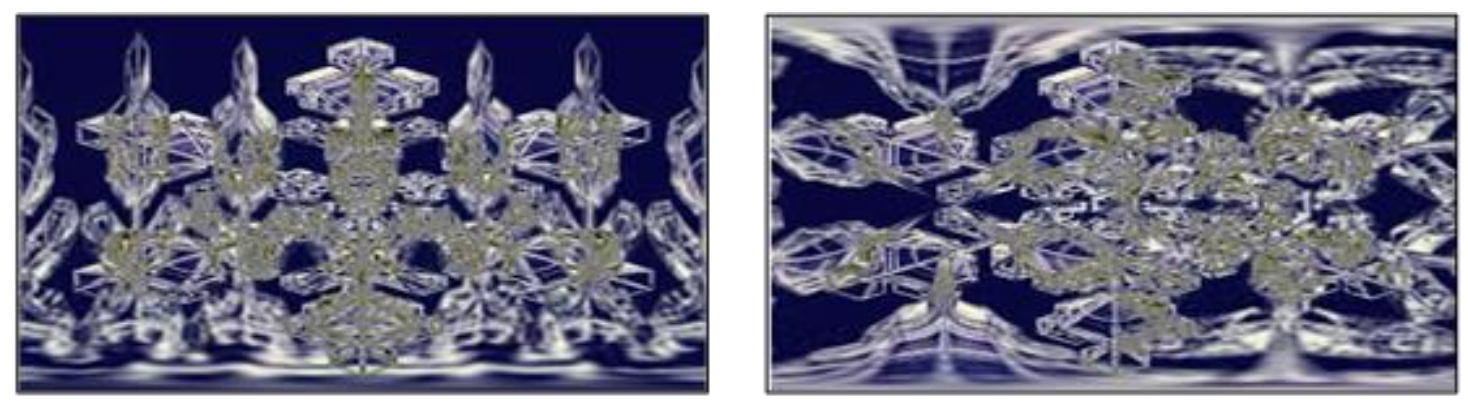

البنبة التصميمية الناتجة عن الثتموج والحركة والتكراز والتُوالد والتراكب
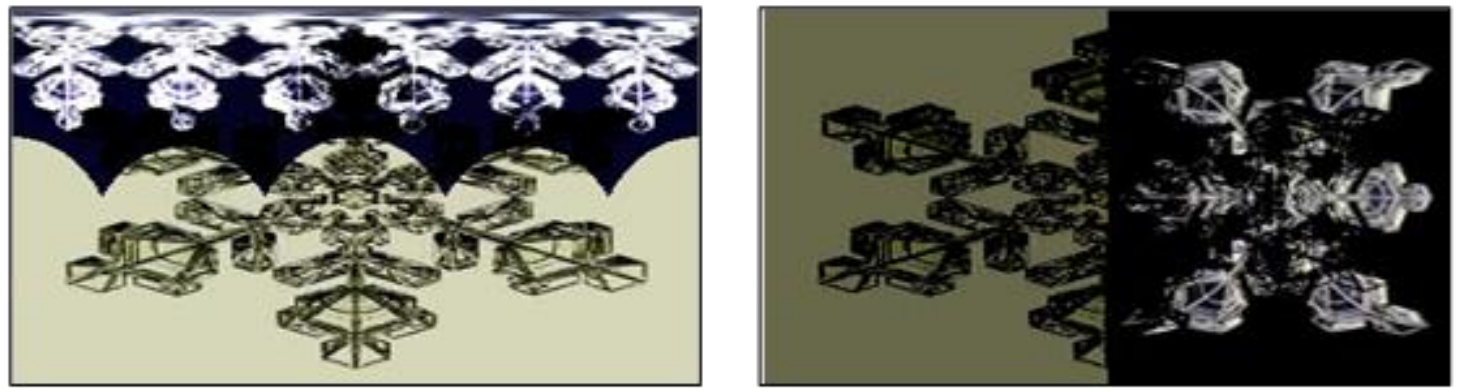

البنية التصميمية الناتجة عن الحركة والتكراز و الثٔو الد و الثزراكب
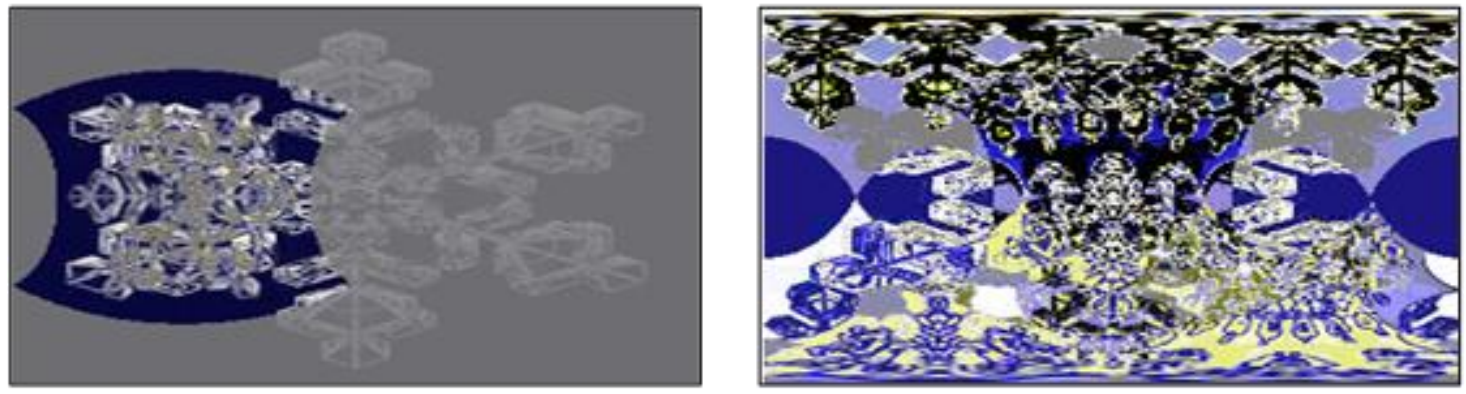

البنية التصميمية الناتجة عن الحركة والتكراز والتو الث و التراكب و التمازج

$$
\text { 9- نتائج البحث : }
$$

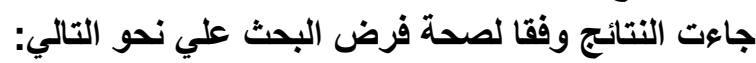
• • تساعد نظرية المورفوجينيك في تتبع الهيئة الثكلية الخارجية للظو اهر الطبيعية والخايا الجينية ومظاهر ها ثنائي الإبعاد

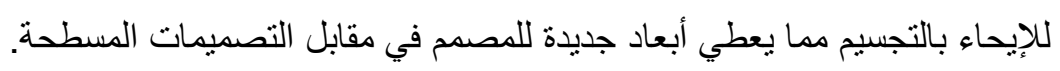
• • ترتبط البنية الهنسية لنظرية المورفوجينيك بالعديد من العمليات الرياضية الني تقدم صياغات غنية ومتثعبة تفيد في

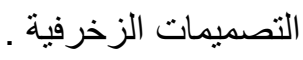


يعد مجال التصميم المورفوجينيك أحدث الدراسات التي تتاولت مصادر التصميم والتي ارتبطت بعدة نظريات منها الهيولية الفر اكتال و التصميم الرقمي و الأوتار و فن الخداع البصري.

ارتبطت نظرية المورفوجينيك بتطور الثكل والتكون الثكلي لنظرية المورفوجيستي والذي يتناول المظهر البنائي الجيني الداخلي و المظهر التركيبي الخارجي للعناصر الطبيعية وإيجاد تقنيات ومهار ات و علوم تقنية للانتقال من الطبيعة إلي التصميم.

تتيح هذه النظرية للمصمم الربط بين المظهر الخارجي للطبيعة وبين البنية الداخلية لها و العلاقة بينها من خلال نظرية المورفوجينيك لابتكار صياغات تصميمية جديدة تفتح مجالا لابتكار تصميمات ثنائية الإبعاد للإيحاء بالتجسيح.

: 10 - التوصيات

الربط بين الفن التثكيلي و العلوم الحيوية والتصميم وتفهم العلاقات النانشئة عنها والكثف عن النظم الإيقاعية والقيم الجمالية .

تعمق دراسة القوانين الرياضية والهندسية التي ترتبط بتفسير بنية نظرية المورفوجينيك من الناحية العملية وربطها بمجال الفن و التصميم وبمجالات جديد خاصة في مجال التصميمات الزخرفية. 11- مصادر ومراجع البحث: 11 1. الفهاد، مروان أحمد؛ قرم، عبد الغني يوسف: (2005) "الأساسيات في الفيزياء الحيوية والطبية" الرياض- مكتبة العبيكان. (- n 1 - alfahad , marwan 'ahmad. alqurm, eabd alghani yusf: (2005) "asasiaat fi alfyzya' altibiyat alhayawiatu" alriyad - maktabat aleubykan.

2. البير، هطلق: (د .ت) موسو عة كوكب الأرض الثاملة_ لبنان- مكتبة لبنان 2. albayr , hithal :) d. t) almawsueat alshshamilat likawkb al'ard - lubnan - maktabat lubnan 3. أمنيمة خفاجي: (2007) "الجينات والحرب الخفبة " دار المعارف ، الطبعة الأولي.القاهرة. 3. 'aminat khifajy: (2007) "aljaynat walharb alkhafiyatu" , dar almaearif , altibeat al'uwlaa , alqahirat.

4. أيسر فاهم وناس (2016)"مورفولوجيا التصميم البار امتري كمدخل لاثر اء الاشكال المتعددة الاسطح" رسالة دكتور اه - غير منشورة،تربية فنية ،جامعة حلوان. 4. 'aysar fahim wanas (2016) "mwrfwlwjya altasmim albaramtryt kamuqadimat li'iithra' al'ashkal almtedd" 'atruhat dukturah - ghyr manshurat, altarbiat alfaniyat, jamieat hulwan. 5. راند حسن عابد حسين :(2018)"مورفولوجيا مخطوطة كليلة ودمنه كمدخل لتاكيد البعد التعبير في التصوير " رسالة ماجستير -غير منشورة،تربية فنية ،جامعة حلو حوان. 5. rand hasan eabid hsyn: (2018) "mwrfwlwjya makhtutat kalilat wadamanat kamuqadimat liltaakid ealaa bued altaebir fi alrsm" risalat majstir - ghyr manshurat, altarbiat alfaniyat , jamieat hulwan.

6. رهام أيهاب خليل-عادل عدلي ابر اهيم : (2020) "منهجية البناء المورفولوجي للحيزات الفراعية" مجلة التصميم

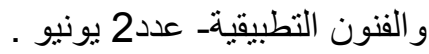

6. riham 'iihab khalil eadil eadli 'iibrahim: (2020) "mnahjiat albina' alsarfii lilfawasil aljazyiyati" majalat altasmim walfunun altatbiqiat - eadad 2 yuniu.

7. سالم العريفي : (2003) "الور اثة ما لها وما عليها"،دار الحرف العربي للطباعة والنشر ، الطبعة الثانية 7. salim alearify: (2003) "alwarathat ma laha wama ealayha" , dar alharf alearabiu liltabaeat walnashr, altibeat althaaniat. 


$$
\text { 8. عمر النجدي: (1996 ) " أبجدية التصميم" الهيئة المصرية العامة للكتاب ، الطبعة الأولي. }
$$

8. eumar alnajdi: (1996) "abjdyt altasmim" , alhayyat almisriat aleamat lilkitab , altabeat al'uwlaa.

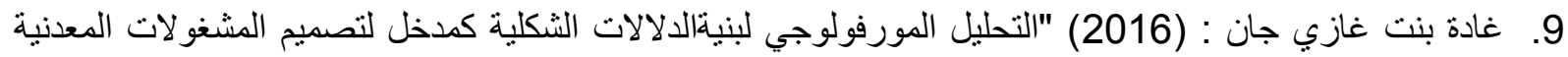

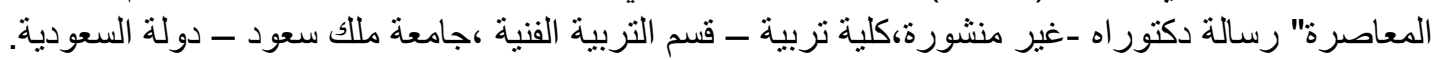
9. ghadatan bnt ghazi ynayr: (2016) "altahlil alsarfiu lihaykal altawaqie alrasmiat kamuqadamat litasmim almashghulat almaedaniat almueasirati" , risalat dukturah ghyr manshurat, kuliyat altarbiat - qism altarbiat alfaniyat , jamieat almalik sueud - almamlakat alearabiat alsaeudiat.

$$
\text { 10.كمال الثيخ حسين :(2002) " الاحياء مجالاتها الحيوية وانتشار ها" دار المنهل اللبنان . }
$$

10. kamal alshaykh husayn: (2002) "alnahdat, mijalatuha alhayawiat waintisharuha" , dar almunahil , lubnan.

$$
\text { 11. محمد حافظ الخولي ،محمد أحمد سلامة: " التصميم بين الفنون التشكيلية والزخرفية" ط1 ر القاهرة . }
$$

11. muhamad hafiz alkhuliu , muhamad 'ahmad salamat: "altasmim bayn alfunun altashkiliat walzakhrifiati", altibeat al'uwlaa , alqahirat.

$$
\text { 12. محمد محسن العيد : (2001) "شفرة الحياة ومعانيها في بناء الكائنات الحية" مجلة النباً . العدد } 54 .
$$

12. muhamad muhsin aleyd: (2001) qanun alhayat wamaeaniha fi bina' alkayinat alhiati. majalat alnab'a. aleadad 54.

$$
\text { 13.نبيل حسن: " الكمبيوتر و العمارة الداخلية " دار الكتب الجامعية للنشر. }
$$

13. nabil husn: "alhasibat waleamarat aldaakhiliati" dar alkutub aljamieiat lilnashr.

14. هدي عبد العزيز محمد مطر :(2006) " نظم الثفرة الور اثية في الكائنات الحية كمصدر لاستحداث صياغات جمالية

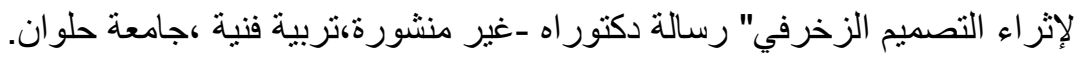

14. hudana eabd aleaziz muhamad mtr: (2006) "anzmat alkawd aljynyi fi alkayinat alhayat kamusadar litatwir alsiygh aljamaliat li'iithra' altasmim alzakhrufi" , 'atrawhat dukturah ghyr manshurat, altarbiat alfaniyat, jamieat hulwan.

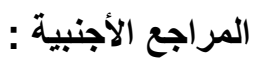

1. E.H.Gombrick:"The Ring of Order".phaidem Press,New York.1984.

2. Michael Hensel:"Synthetic life Architectures,Ramification and potentials of a literal Biological Paradigm for Architectural Design",A.D.Morphogenetic Design,Wiley,Academy.2006,

3. Przemyslaw Prusinkiewicz: Visual Models of Morphogenesis-Department of ComputerScience-University of Calgary -Calgary, Alberta -Canada T2N 1N4-1994.

4. Stanislav Roudavski: Towards Morphogenesisin Architecture- international journal of architectural computing- September 2009

5. Christian Morgner: The morphogenesis of art districts: Case studies of Williamsburg, NYC and 798,Beijing- Belgeo [En ligne], 3 | 2014.

6. Arnold,neumaier: Mathematical modeling.institute four mathematic, university Aat wien. Viana.2003. 
7. Jaap A. Kaandorp1, Peter M. A. Sloot1, Roeland M. H. Merks1 y, Rolf P. M. Bak2, Mark J. A. Vermeij3 and Cornelia Maier(Morphogenesis of the branching reef coral Madracis mirabilis) Proceedings of the Royal Society B: Biological Sciences · February 2005

مواقع الانتر انت:

1-www.siat.sfu.ca.

2-https://www.researchgate.net/publication/37853382

3- https://www.Bombsite.COM/lewitt/lewitt3.html.

4- www.bezra,com/whiteDesert.ASP.

5- http://www.its.caltech.edu/ atomic/snowcrystals/

6- http://www.planetseed.com/ar/sciencearticle/lbrq-ndm-tfqd-lsm-tw-znh

7-https://jeb.biologists.org/content/jexbio/212/5/662.full.pdf

8- http://rspb.royalsocietypublishing.org/subscriptions 